\title{
Guatemala articles in the Science Citation Index Expanded: bibliometry of subjects, collaboration, institutions and authors
}

\author{
Julián Monge-Nájera ${ }^{1}$ and Yuh-Shan $\mathrm{Ho}^{2 *}$ \\ 1. Laboratorio de Ecología Urbana, Vicerrectoría de Investigación, Universidad Estatal a Distancia, 2050 San José, Costa \\ Rica; julianmonge@gmail.com \\ 2. Trend Research Centre, Asia University, Taichung 41354, Taiwan; ysho@asia.edu.tw \\ * Correspondence
}

Received 07-IX-2017. Corrected 08-IX-2017. Accepted 11-IX-2017.

\begin{abstract}
Guatemala, with 16 million inhabitants, is the largest economy of Central America and should have the largest scientific output of the region. To assess its productivity and impact, we analyzed the 3380 Guatemala articles included in the SCI-expanded in June, 2017. Most Guatemala documents are articles in English, deal with nutrition and health problems, and have a mean of 7.4 authors per article. Also in this particular database, citation lifespan is 40 years, and citations are higher for articles in English (twice more than those in Spanish), for reviews (mean 24 citations per review) and for studies resulting from international collaboration, which is done mostly with the USA and Mexico. The most productive institutions are the Center for Studies of Sensory Impairment (CESSIAM), the universities of San Carlos and El Valle, and the Central American Nutrition Institute (INCAP, but it has decreased productivity in recent years). The most productive researchers are N.W. Solomons, R. Bressani, L.G. Elías, C. Rolz and A. Cáceres. Guatemala represents a particular case in Central America because its high quality research is dependent on particular researchers rather than on institutions, and because the total output is well under the expectation. The productivity and citation of Guatemalan science in the 18 journals published in the country, and in other journals which are also not covered in the SCI-expanded, remain unknown. Nevertheless, the historical trend is positive, with a clear growth of international collaboration, productivity and citation. Rev. Biol. Trop. 66(1): 312-320. Epub 2018 March 01.
\end{abstract}

Key words: Web of Science, Latin American science, scientific output, most productive institutions and authors, research fields.

Guatemala, with 16 million inhabitants, is the largest economy of Central America and should have the largest scientific output of the region. However, this is not the case: with a per capita Gross Domestic Product of $\$ 4000$, Guatemala is below its neighbors Mexico (\$18000) and Honduras (\$ 4700). A series of dictatorships that started in 1871 , and a genocidal civil war from 1960 to 1996, prevented the country from developing a proper scientific establishment and even from properly feeding its people (Marini \& Gragnolati, 2003). For this reason, Guatemala does not occupy the expected place in the ranking of science in the Central American context.
Previous studies in this series have analyzed the scientific output of other Central American countries. One of the smallest countries in the isthmus, Costa Rica, leads the region with nearly 7000 publications in the database, about half of them produced in international collaboration and dominated by biology and medicine (Monge-Nájera \& Ho, 2012). The second most productive Central American country is Panama, also a small country, with over 4800 publications that show strong collaboration with the USA and concentration on forest ecology (Monge-Nájera \& Ho, 2015). The third and fourth places are occupied by the largest countries, Honduras and Nicaragua. 
Honduras, with 1146 publications mostly about health and agriculture, is the Central American country with less scientific journals (MongeNájera \& Ho, 2017b). Nicaragua has over 800 publications in the database, dominated by medical research in which Nicaraguan scientists play a secondary role within international teams (Monge-Nájera \& Ho, 2017a). El Salvador, second smallest country in the region, is also among the less productive, with 788 publications mostly from the social sciences (Monge-Nájera \& Ho, 2017c).

Even though there are no in-depth studies about the scientific output of Guatemala, it has been included in a series of larger studies from 1982 through 2015. In the transition from the decade of 1970 to that of 1980, Guatemala was increasing the number of articles included in the Science Citation Index (SCI) database (Blickenstaff \& Moravcsik, 1982), but still that meant a low number of only 18 articles (Garfield, 1983). They had 96 citations in journals covered in the index, which led Garfield (1983) to place it in the world's middle impact category, despite the fact that in the SCI countries with very low numbers produce misleading results (for example, one country with 1 article and 5 citations is considered as successful as one with 1000 articles and 5000 citations, albeit clearly their real impact in world science is quite different).

In the decade of 1980 , around 40 Guatemalan articles per year were included in the SCI and Guatemala occupied the 83rd. place in the list (Braun, Glanzel \& Schubert, 1988; Lewison, Fawcett-Jones \& Kessler, 1993), accumulating to 1993 nearly 600 articles, better than its similarly sized neighbor Honduras, which only had 108 articles (Garfield, 1995; Fernández, Gómez \& Sebastian, 1998).

Considering the economically active population, Guatemala was just under the Latin American average in productivity (DeMoyaAnegón \& Herrero-Solana, 1999), but this result, based on all scientific fields, did not include computing science, where Guatemala only had one article in the year 2007, just like Honduras, and far below Mexico, which had
5000 (Rojas-Sola \& Jordá-Albiñana, 2009). Finally, the most recent study reported that Guatemala only has three Open Access scientific journals (Alonso \& González, 2015).

\section{MATERIALS AND METHODS}

We used the Science Citation Index Expanded (SCI-EXPANDED), Web of Science Core Collection, Thomson Reuters. We searched for the word "Guatemala" in the address field and found 3697 documents, published between 1900 and 2016 (Date of search: June $19^{\text {th }}, 2017$ ). Results were refined by countries/territories with Guatemala. We discarded 63 documents with "Guatemala" in the address field that were not actually from the country (for example USDA, Aphis, Guatemala Medfly Methods Stn, Usemb Aphis Unit 3319, Apo, AA 34024; Rua Guatemala, 190 Alto Rio Preto, BR-15020260 Sao Jose Do Rio Preto, SP, Brazil; and Ctr Dis Control, Ctr Infect Dis, Div Parasit Dis, Med Entomol Res Unit Guatemala, Atlanta, GA 30333). In total, 3634 documents were finally found as publications by authors from Guatemala (including several types of document). Only 2380 that were formal articles were further analysed.

For international collaborative documents, we reclassified articles from England, Scotland, Northern Ireland, and Wales as "United Kingdom" (UK). Articles from the Union of Soviet Socialist Republics (USSR) were checked and reclassified as being from Russia (Ho et al., 2016).

To investigate citations, five indicators $C_{\text {year }}, T C_{\text {year }}, C_{0}, T C P Y$, and $C P P_{2016}$ were applied. The "impact of an article in recent year" is considered as the number of citation from Web of Science Core Collection of an article in the recent year only, $C_{\text {year }}(\mathrm{Ho}, 2012)$, for example 2016, is referred to as $C_{2016}$, and citations of articles are considered as the total number of citations since publication to the end of the recent year was referred to as $T C_{\text {year }}$ (Wang et al., 2011; Chuang et al., 2011). $C_{0}$, the total number of citations of an article in its publication year (Ho and Kahn, 2014). TCPY, 
the citations per year ( $T C_{\text {year }} /$ year) $(H o, 2012)$. $C P P_{2016}$, citations per publication $\left(C P P_{2016}=\right.$ $T C_{2016} / T P$ ) (Ho, 2012; Elango \& Ho, 2017).

Affiliations in Federal Republic of Germany (Fed Rep Ger) and German Democratic Republic (Ger Dem Rep) were reclassified as being from Germany (Ho, 2014). Affiliations in Zaire were checked and reclassified as from the Democratic Republic of the Congo (Dem Rep Congo) (Pouris \& Ho, 2014). Affiliations in Yugoslavia were checked and reclassified as being from Slovenia (Ho, 2014). Affiliations in the Union of Soviet Socialist Republics (USSR) were checked and reclassified as being from Russia (Ho, 2012). Similarly, Acad Sci USSR were checked and reclassified as being from the Russian Acad Sci (Chuang \& Ho, 2014).

Tables appear in Digital Appendix 1 and additional figures in Digital Appendix 2. References for the main text appear in the printed version, while references to literature cited only on tables and figures are included in their own digital appendix as "Additional References".

\section{RESULTS}

Articles greatly dominate the Guatemalan presence in the SCIE, followed by meeting abstracts; all other publication types are minor in number (Fig. 1). The most cited types of publication in this database are reviews, with a mean of 24 citations, followed by proceedings (21 citations) and articles (19 citations); letters and meeting abstracts are seldom cited (Fig. 1, Table 1).

Correction notes have the highest number of authors, with a mean of ten authors per publication, followed by articles (7.4 authors), and meeting abstracts (6 authors; Table 1).

The majority of articles in this database are in English, followed by Spanish (10\%) and minimal numbers in French, Portuguese and German (Table 2). In comparison with those in Spanish, articles in English had twice the number of coauthors and received seven times more citations (Table 2).

Publications received most citations in the third year, and then citation falls gradually

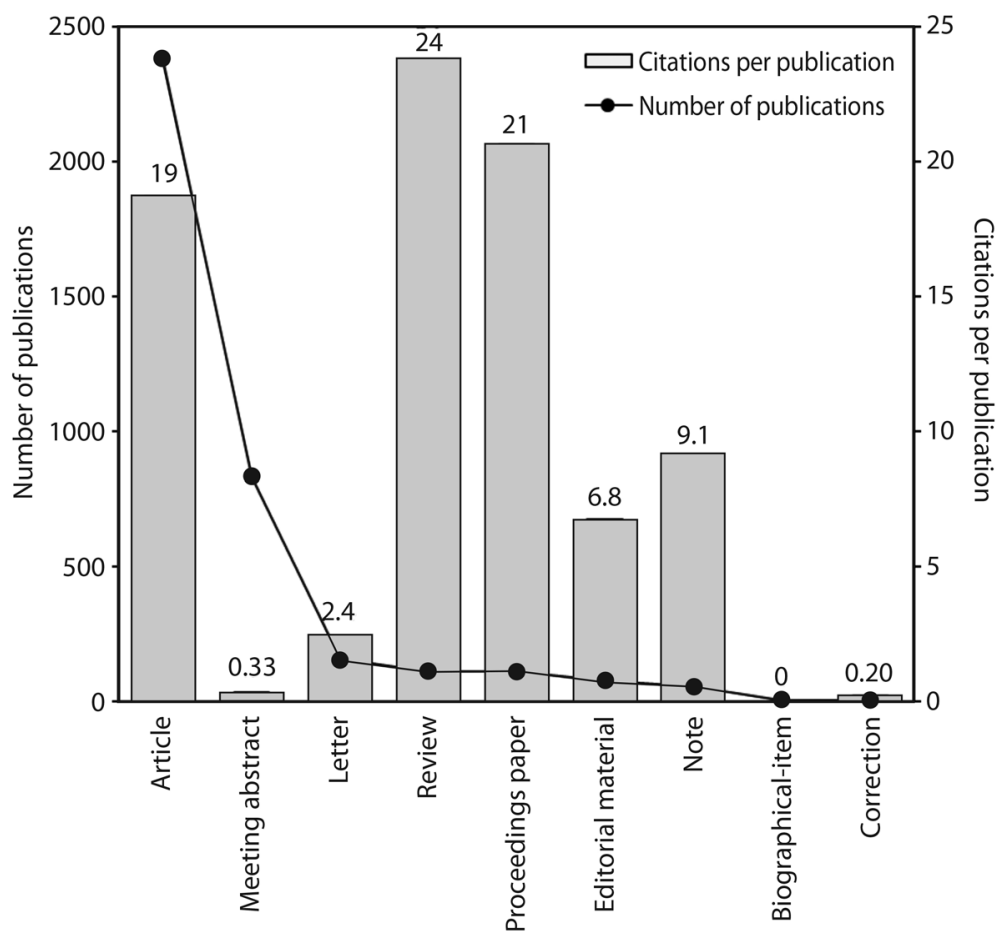

Fig. 1. Percentage of publications and number of journals in each Web of Science category. 


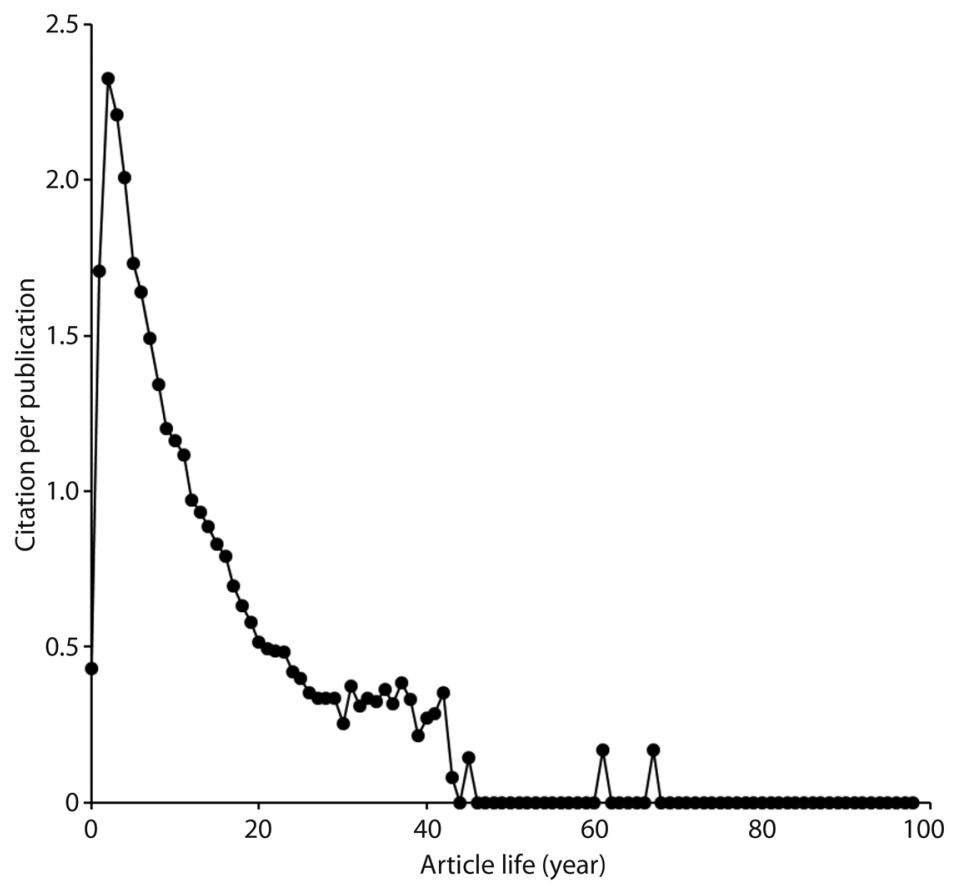

Fig. 2. Distribution of citations versus article age in years.

for three decades, reach a plateau in the fourth decade and articles basically stop being cited after 40 years (Fig. 2).

The SCIE records few citations for Guatemalan publications before 1970, when the literature mostly was not available in digital form, and afterwards peaked in output in the mid 1970s and again around the year 2000; in the same period citation has increased constantly since the 1990s (Fig. 3).

Both productivity and citation are higher for international publications than for strictly Guatemalan works (Fig. 4).

According to Web of Science categories, the highest percentage of publication are in the fields of Nutrition and dietetics; Public, environmental and occupational health; and Tropical medicine (Fig. 5), while distribution of publications by number of journals is dominated by Pharmacology, Plant Sciences and Public, environmental and occupational health (Fig. 5). Agriculture and nature receive little research attention (Table 3).
A larger number of publications appeared in journals from the nutrition and health categories, namely Archivos Latinoamericanos de Nutrición, American Journal of Clinical Nutrition and American Journal of Tropical Medicine and Hygiene; however there is no strong dominance, the journal with most articles (Archivos) only had $6.7 \%$ (Table 4).

Collaboration with foreign institutions is on the rise in Guatemalan science, and the leading collaborators are institutions from the USA, Mexico and the United Kingdom (Fig. 6). The USA clearly dominated, with $49 \%$ of papers, while most countries had $5 \%$ or less (Table 5).

When only the geographically closest countries are analyzed, the rapid increase in collaboration stands out and the leading countries are in Central and South America (Fig. 7). Mexico co-produced $12 \%$, Costa Rica $5 \%$ and Colombia $4 \%$ (Table 5).

For the top cited articles, the historical citation pattern differs, some stay relatively constant before a final slow decline, some have clear peaks (Figure 8). 


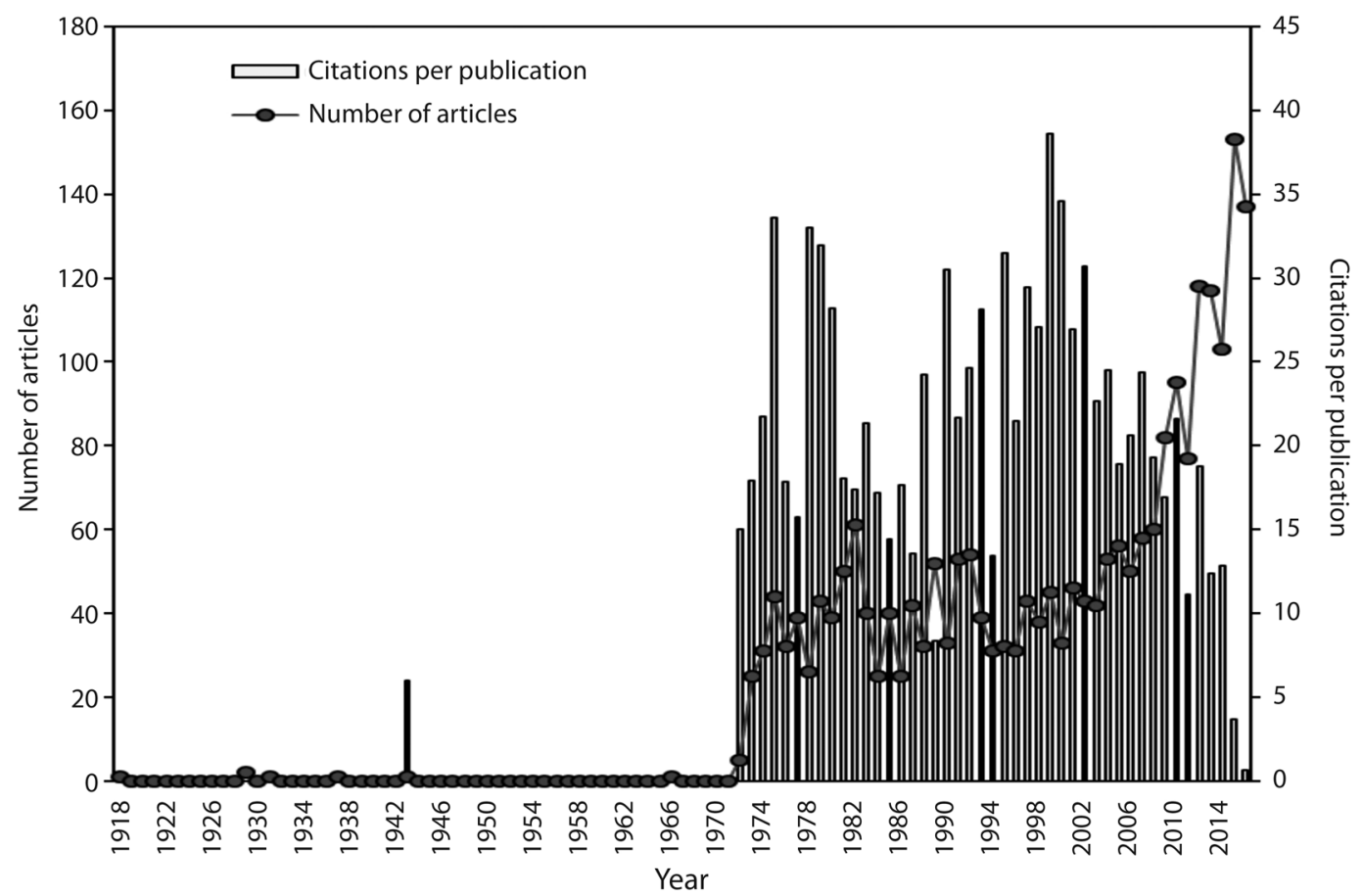

Fig. 3. Distribution of articles and citations per publication from 1918 through 2016.

Lifespan for top cited articles ranges from less than 2 to 14 years, but mostly is around 4 or 5 years (Fig. 9).

For the top cited articles in 2016, a value that has been established by Ho (2012) to allow for meaningful meta-analyses, the historical citation is a growing curve (Fig. 10) that also appears for top cited articles by total citation (Fig. 11) and for articles in both the top ten $T C_{2016}$ and $C_{2016}$ (Fig. 12).

Top producing Guatemalan institutions have three basic historical patterns: steady production (Center for Studies of Sensory Impairment, CESSIAM); rapid growth (Universities of San Carlos and del Valle), and strong reduction (Central American Nutrition Institute, INCAP; Figure 13). Even though it now has only a limited presence, in its early years the INCAP was a powerful institution that accumulated $21 \%$ of all Guatemalan production in the SCIE. The public universities and the sensory impairment center CESSIAM produced the other important proportions of publications (Table 6).

The top five researchers signing from Guatemalan institutions were N.W. Solomons, R. Bressani, L.G. Elias, C. Rolz and A. Cáceres (Table 7). Noel Solomons is the founder of the CESSIAM and an expert in the relationship between food and health; R. Bressani was the editor of the journal Archivos Latinoamericanos de Nutrición and a nutrition expert at INCAP; Luis G. Elías was also a nutrition expert at INCAP; C. Rolz is a chemical engineer at the Universidad del Valle who has worked in reducing the environmental impact of coffee and cane production; and A. Cáceres (Universidad de San Carlos) is an expert in the identification of medical compounds from Guatemalan plants.

When Web of Science categories are analyzed, the citation pattern oscillated widely with time, with no clear overall trend to increase or decrease (Fig. 14). 


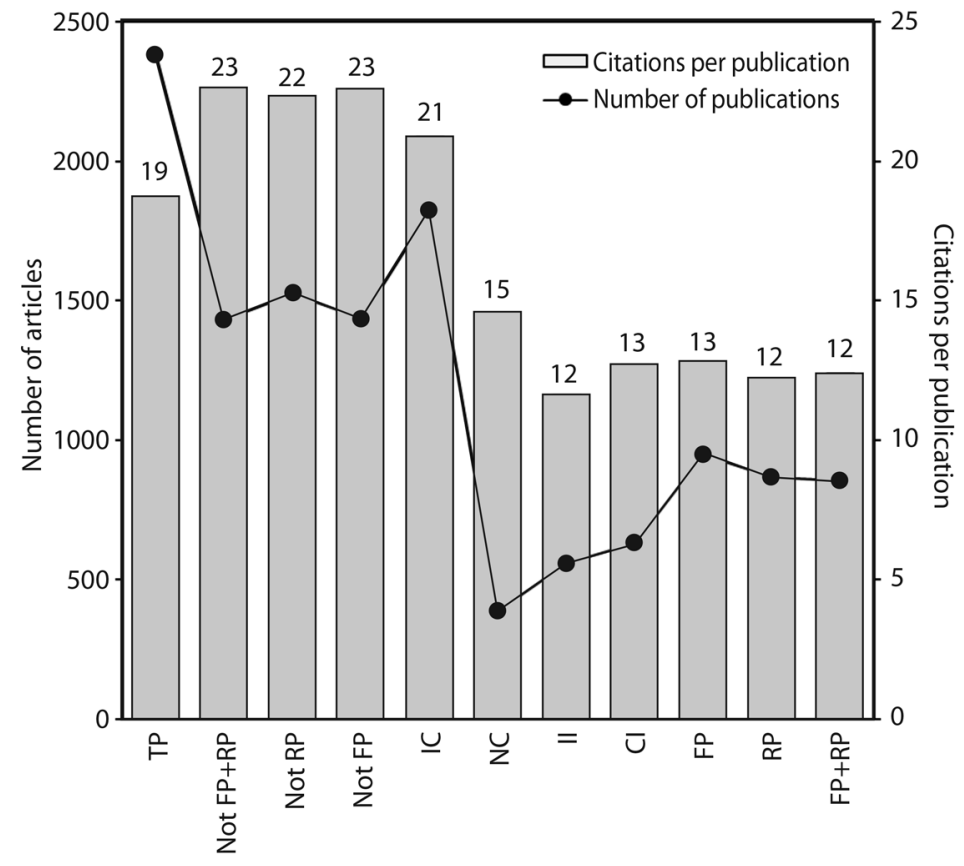

Fig. 4. Productivity and citation according to nationality in local and internationally produced articles. TP: total articles. Not FP+RP: both first and corresponding authors are not from Guatemala. Not RP: corresponding author is not from Guatemala. Not FP: first author is not from Guatemala. IC: internationally collaborative papers. NC: nationally collaborative papers. II: institutional independent papers. CI: Guatemala independent papers. FP: first author is from Guatemala. RP: corresponding author is from Guatemala. FP+RP: both first and corresponding authors are from Guatemala.

The overall top cited articles show a clear concentration in health, particularly nutrition (Table 8). The top cited articles deal with an international study of the human papillomavirus; and treatments for asthma, adenocarcinoma, diarrhea, pneumonia, influenza, psoriasis and hypertension (Table 8).

For publications in which all authors are from Guatemalan institutions, the top cited articles are about nutrition in children, clinical efficacy of ciprofloxacin and the anti-gonorrhoeal activity of Guatemalan plants (Table 9).

\section{DISCUSSION}

The domination of articles over other types of publication is typical of Latin American countries, and Guatemala is not an exception. The reason for this seems to be the fact that only articles qualify for salary improvement in Latin American universities (Sábato \& Botana,
1993). The nearly universal use of English in the articles from Guatemala in the SCI-expanded does not reflect a characteristic of Guatemalan science, which produces many articles in Spanish, but reflects the fact that the SCIexpanded is biased against journals that are not in English and that are published outside the USA and Western Europe (Monge-Nájera, 2014). In fact, none of the 18 Guatemalan scientific journals are included in the SCIexpanded (http://ip-science.thomsonreuters. com/cgi-bin/jrnlst/jloptions.cgi?PC=K).

The fact that the SCI-expanded stops counting citations after the second year (Garfield, 2006) greatly affects Latin American science because most citations there take place after the second year (Monge-Nájera \& Ho, $2012 ; 2015 ; 2017 \mathrm{a}-\mathrm{c})$. For those articles that are covered in the database, the patterns are also similar to those previously reported for other Central American countries, i.e. articles 
in English are more cited because they have a larger readership, reviews are more cited because they summarize knowledge, and international projects are more cited because they are better funded and are of more general interest, usually in the field of health research (Monge-Nájera-\& Ho, 2017a-c).

The institutions with growing productivity in the database are universities with contrasting characteristics: the University of San Carlos, among the oldest in the continent (founded in 1676), is a public institution of 200000 students, while Del Valle Universiy is a small private institution (10 000 students) founded in 1966, but both are overcoming the disdain for publication typical of Guatemalan universities, thanks in part to the arrival of a new generation of researchers trained in Europe and the USA (Martínez-Folgar \& Salomon, 2017).

The CESSIAM, a NGO with a steady production about the relationship of food and health founded in 1985, has always had research as key objective and has been under the same leadership for decades, which can explain why its output has remained good and stable over the years (http://www.inffoundation.org/research/cessiam.htm). Finally, the fall in productivity of the Central American Nutrition Institute, INCAP (www.incap.int), financed by the PAHO and private foundations, might reflect a change in leadership (M. Campos, pers. commun.).

The top authors from Guatemala match the list of top institutions, suggesting that they are the motivating leaders of productivity in their institutions. However, since they seem to have no peers of the same level in their institutions, those institutions may lose a significant part of their output if those particular scientists stop working for them, another known problem of science in Latin America (Nájera, NielsenMuñoz, \& Azofeifa, 2010). A positive finding is, that contrary to other Central American countries (Monge-Nájera \& Ho, 2017, a-c), Guatemalan authors are in some cases the leaders in the research teams signing high impact articles in the Science Citation Index.
Serious economic inequality, and a lack of interest in scientific research, keep Guatemala low in the Central American ranking of scientific productivity (Martínez-Folgar \& Salomon, 2017); only Honduras has less articles in the database (Monge-Nájera \& Ho, 2017b), but the growing trend in productivity and citation in the SCI-expanded is ground for optimism. The productivity and citation of Guatemalan science in the 18 journals published in the country, and in other journals also not covered in the SCI-expanded, remain unknown and must be borne in mind as a limitation of the present study, which did not include all of the scientific output of the country but only those documents that are included in the SCI-expanded. Previous work has shown that, for Latin American countries, the number of citations not included in the SCI-expanded may greatly outnumber citations in that database (Monge-Nájera, 2014).

In conclusion, Guatemala represents a particular case in Central America because its high quality research is highly dependent on particular researchers rather than on institutions, and because the total output is well under the expectation. Nevertheless, the historical trend is positive, with a clear growth of international collaboration, productivity and citation.

\section{ACKNOWLEDGMENTS}

We thank Carlos Morales, Francisco Hernández and anonymous reviewers for comments to improve the manuscript.

\section{RESUMEN}

Artículos de Guatemala en el Science Citation Index Expanded: Bibliometría de sujetos, colaboración, instituciones y autores. Guatemala, con 16 millones de habitantes, es la mayor economía de Centroamérica y, por tanto, podría tener la mayor producción científica de la región. Para evaluar su productividad y su impacto, en junio 2017 analizamos los 3380 artículos de Guatemala incluidos en el SCI-ampliado. La mayoría de los documentos de Guatemala son artículos en inglés, tratan problemas de nutrición y salud y tienen una media de 7.4 autores por artículo. También en esta base de datos en particular, los artículos siguen siendo citados durante 40 años, y se citan más los artículos en inglés (dos veces más que en español), 
las revisiones (media: 24 citas por artículo de revisión) y los estudios resultantes de colaboración internacional, dominada por Estados Unidos y México. Las instituciones más productivas son el Centro de Estudios de Deterioro Sensorial CESSIAM, las universidades de San Carlos y del Valle, y el Instituto Centroamericano de Nutrición INCAP (pero el último ha disminuido la productividad en los últimos años). Los investigadores más productivos son N.W. Solomons, R. Bressani, L.G. Elías, C. Rolz y A. Cáceres. Guatemala representa un caso particular en Centroamérica, porque su investigación de alta calidad depende en gran medida de investigadores particulares, no tanto de las instituciones, y porque la producción total está muy por debajo de las expectativas para un país con esa población. La productividad y el impacto de la ciencia guatemalteca en las 18 revistas publicadas en el país, y en otras revistas que tampoco están cubiertas en el SCI-ampliado, siguen siendo desconocidos. Sin embargo, la tendencia histórica es positiva, con un claro crecimiento de la colaboración internacional, la productividad y el impacto.

Palabras clave: Web of Science, ciencia latinoamericana, productividad científica, autores e instituciones más productivas, campos de investigación.

\section{REFERENCES}

Alonso, J. A. G., \& González, Y. P. (2015). Análisis de las revistas latinoamericanas de Acceso Abierto. El caso Ecuador. Revista Publicando, 2(2), 12-23.

Blickenstaff, J., \& Moravcsik, M. (1982). Scientific output in the Third World. Scientometrics, 4(2), 135-169.

Braun, T., Glänzel, W., \& Schubert, A. (1988). The newest version of the facts and figures on publication output and relative citation impact of 100 countries 19811985. Scientometrics, 13(5-6), 181-188.

Chuang, K. Y., \& Ho, Y. S. (2014). Bibliometric profile of top-cited single-author articles in the Science Citation Index Expanded. Journal of Informetrics, 8(4), 951-962.

Chuang, K. Y., Wang, M. H., \& Ho, Y. S. (2011). Highimpact papers presented in the subject category of water resources in the Essential Science Indicators database of the Institute for Scientific Information. Scientometrics, 87(3), 551-562.

De Moya-Anegón, F., \& Herrero-Solana, V. (1999). Science in America Latina: a comparison of bibliometric and scientific-technical indicators. Scientometrics, 46(2), 299-320.

Elango, B., \& Ho, Y. S. (2017). A bibliometric analysis of highly cited papers from India in Science Citation Index Expanded. Current Science, 112(8), $1653-1658$
Fernández, M. T., Gómez, I., \& Sebastián, J. (1998). La cooperación científica de los países de América Latina a través de indicadores bibliométricos. Interciencia, 23(6), 328-337.

Garfield, E. (1983). Mapping science in the Third World. Science and Public Policy, 10(3), 112-127.

Garfield, E. (1995). Quantitative analysis of the scientific literature and its implications for science policymaking in Latin America and the Caribbean. Bulletin of PAHO, 29(1), 87-95.

Garfield, E. (2006). "The History and Meaning of the Journal Impact Factor”. JAMA. 295(1), 90-93.

Ho, Y. S. (2012). Top-cited articles in chemical engineering in Science Citation Index Expanded: A bibliometric analysis. Chinese Journal of Chemical Engineering, 20(3), 478-488.

Ho, Y. S. (2014). A bibliometric analysis of highly cited articles in materials science. Current Science, 107(9), $1565-1572$.

Ho, Y. S., \& Kahn, M. (2014). A bibliometric study of highly cited reviews in the Science Citation Index Expanded ${ }^{\mathrm{TM}}$. Journal of the Association for Information Science and Technology, 65(2), 372-385.

Lewison, G., Fawcett-Jones, A., \& Kessler, C. (1993). Latin American scientific output 1986-91 and international co-authorship patterns. Scientometrics, 27(3), 317-336.

Marini, A., \& Gragnolati, M. (2003). Malnutrition and poverty in Guatemala. Washington, D.C.: World Bank.

Martinez-Folgar, K., \& Salomon, V. M. (2017). Publicación científica estudiantil: un vistazo a la realidad guatemalteca. Educación Médica, 18(1), 79-79.

Monge-Nájera, J. (2014). The invalidity of the impact factor as indicator of the impact of Latin American scientific journals. Revista de Biologia Tropical, 62(1), 9-13.

Monge-Nájera, J., \& Ho, Y. S. (2012). Costa Rica Publications in the Science Citation Index Expanded: A bibliometric analysis for 1981-2010. Revista de Biología Tropical, 60(4), 1649-1661.

Monge-Nájera, J., \& Ho, Y. S. (2015). Bibliometry of Panama publications in the Science Citation Index Expanded: publication type, language, fields, authors and institutions. Revista de Biología Tropical, 63(4), $1255-1266$

Monge-Nájera, J., \& Ho, Y. S. (2017a). Bibliometrics of Nicaraguan publications in the Science Citation Index Expanded. Revista de Biología Tropical, 65(2), 643-655. 
Monge-Nájera, J., \& Ho, Y. S. (2017b). Honduras publications in the Science Citation Index Expanded: institutions, fields and authors. Revista de Biología Tropical, 65(2), 657-668.

Monge-Nájera, J., \& Ho, Y. S. (2017c). El Salvador publications in the Science Citation Index Expanded: subjects, authorship, collaboration and citation patterns. Revista de Biología Tropical, 65(2), 657-668.

Monge-Nájera, J., Nielsen-Muñoz, V., \& Azofeifa, A. B. (2010). Determinants of scientific output: an in-depth view of the productivity of tropical botanist and conservationist, Luis Diego Gómez Pignataro. Revista de Biología Tropical, 58(4), 1093-1114.
Pouris, A., \& Ho, Y. S. (2014). Research emphasis and collaboration in Africa. Scientometrics, 98(3), 2169-2184

Rojas-Sola, J. I., \& Jordá-Albiñana, B. (2009). Análisis bibliométrico de las publicaciones venezolanas en la categoría ciencias de la computación en la base de datos JCR (1997-2007). Interciencia, 34(10).

Sábato, J., \& Botana, N. (1993). La ciencia y la tecnología en el desarrollo futuro de América Latina. Arbor, $146(575), 21$

Wang, M. H., Fu, H. Z., \& Ho, Y. S. (2011). Comparison of universities' scientific performance using bibliometric indicators. Malaysian Journal of Library \& Information Science, 16(2), 1-19.

See Digital Appendix at: / Ver Apéndice digital en: https://revistas.ucr.ac.cr/index.php/rbt 


\section{DIGITAL APENDIX: ADDITIONAL REFERENCES}

Althabe, F., Belizan, J. M., McClure, E. M., Hemingway-Foday, J., Berrueta, M., Mazzoni, A., ..., \& Buekens, P. M. (2015). A population-based, multifaceted strategy to implement antenatal corticosteroid treatment versus standard care for the reduction of neonatal mortality due to preterm birth in low-income and middle-income countries: The ACT cluster-randomised trial. Lancet, 385(9968), 629-639.

Arathoon, E. G., Gotuzzo, E., Noriega, L. M., Berman, R. S., DiNubile, M. J., \& Sable, C. A. (2002). Randomized, double-blind, Multicenter study of caspofungin versus amphotericin B for treatment of oropharyngeal and esophageal candidiases. Antimicrobial Agents and Chemotherapy, 46(2), 451-457.

Belizan, J. M., Villar, J., Pineda, O., Gonzalez, A. E., Sainz, E., Garrera, G., \& Sibrian, R. (1983). Reduction of blood pressure with calcium supplementation in young adults. JAMA-Journal of the American Medical Association, 249(9), 1161-1165.

Bhutta, Z. A., Bird, S. M., Black, R. E., Brown, K. H., Gardner, J. M., Hidayat, A., ..., \& Shankar, A. (2000). Therapeutic effects of oral zinc in acute and persistent diarrhea in children in developing countries: pooled analysis of randomized controlled trials. American Journal of Clinical Nutrition, 72(6), 1516-1522.

Bhutta, Z. A., Black, R. E., Brown, K. H., Gardner, J. M., Gore, S., Hidayat, A., ..., \& Shankar, A. (1999). Prevention of diarrhea and pneumonia by zinc supplementation in children in developing countries: Pooled analysis of randomized controlled trials. Journal of Pediatrics, 135(6), 689-697.

Bohm, M., Collen, B., Baillie, J. E. M., Bowles, P., Chanson, J., Cox, N., ..., \& Zug, G. (2013). The conservation status of the world's reptiles. Biological Conservation, 157, 372-385.

Carlo, W. A., Goudar, S. S., Jehan, I., Chomba, E., Tshefu, A., Garces, A., ..., \& Wright, L. L. (2010). Newborncare training and perinatal mortality in developing countries. New England Journal of Medicine, 362(7), 614-623.

Chuang, K. Y., Ho, Y. S. (2014). Bibliometric profile of top-cited single-author articles in the Science Citation Index Expanded. Journal of Informetrics, 8(4), 951-962.

Chuang, K. Y., Wang, M. H., \& Ho, Y. S. (2011), High-impact papers presented in the subject category of water resources in the Essential Science Indicators database of the Institute for Scientific Information.

Scientometrics, 87(3), 551-562.

Crozier, R. H., Dix, M. W. (1979), Analysis of two genetic models for the innate components of colony odor in social hymenoptera. Behavioral Ecology and Sociobiology, 4(3), 217-224.

de Sanjose, S., Quint, W. G. V., Alemany, L., Geraets, D. T., Klaustermeier, J. E., Lloveras, B., .., \& Bosch, F. X. (2010). Human papillomavirus genotype attribution in invasive cervical cancer: a retrospective crosssectional worldwide study. Lancet Oncology, 11(11), 1048-1056.

Diaz, S., Demissew, S., Carabias, J., Joly, C., Lonsdale, M., Ash, N., ..., \& Zlatanova, D. (2015). The IPBES conceptual framework: Connecting nature and people. Current Opinion in Environmental Sustainability, 14, $1-16$.

Elango, B., \& Ho, Y. S. (2017), A bibliometric analysis of highly cited papers from India in Science Citation Index Expanded. Current Science, 112(8), 1653-1658.

Fuchs, C. S., Tomasek, J., Yong, C. J., Dumitru, F., Passalacqua, R., Goswami, C., ..., \& Tabernero, J. (2014). Ramucirumab monotherapy for previously treated advanced gastric or gastro-oesophageal junction adenocarcinoma (REGARD): an international, randomised, multicentre, placebo-controlled, phase 3 trial. Lancet, 383(9911), 31-39. 
Habicht, J. P., Martorell, R., Yarbrough, C., Malina, R. M., \& Klein, R. E. (1974). Height and weight standards for preschool-children: How relevant are ethnic differences in growth potential. Lancet, 303(7858), 611-614.

Herwaldt, B. L., Ackers, M. L., Farrar, J., Richardson, S., Nelson, R., Fletcher, M., ..., \&and Messonnier, M. (1997). An outbreak in 1996 of cyclosporiasis associated with imported raspberries. New England Journal of Medicine, 336(22), 1548-1556.

Ho, Y. S. (2012). Top-cited articles in chemical engineering in Science Citation Index Expanded: A bibliometric analysis. Chinese Journal of Chemical Engineering, 20(3), 478-488.

Ho, Y. S. (2014), A bibliometric analysis of highly cited articles in materials science. Current Science, 107(9), 15651572.

Ho, Y. S., \& Kahn, M. (2014). A bibliometric study of highly cited reviews in the Science Citation Index Expanded ${ }^{\mathrm{TM}}$. Journal of the Association for Information Science and Technology, 65(2), 372-385.

Kosoy, R., Nassir, R., Tian, C., White, P. A., Butler, L. M., Silva, G., ..., \& Seldin, M. F. (2009). Ancestry informative marker sets for determining continental origin and admixture proportions in common populations in America. Human Mutation, 30(1), 69-78.

Langley, R. G., Elewski, B. E., Lebwohl, M., Reich, K., Griffiths, C. E. M., Papp, K., ..,, \& Papavassilis, C. (2014). Secukinumab in plaque psoriasis: Results of two phase 3 trials. New England Journal of Medicine, 371(4), 326-338.

Laurance, W. F., Useche, D. C., Rendeiro, J., Kalka, M., Bradshaw, C. J. A., Sloan, S. P., ..., \& Zamzani, F. (2012). Averting biodiversity collapse in tropical forest protected areas. Nature, 489(7415), 290-294.

Lazaridis, I., Patterson, N., Mittnik, A., Renaud, G., Mallick, S., Kirsanow, K., ..., \& Krause, J. (2014). Ancient human genomes suggest three ancestral populations for present-day Europeans. Nature, 513(7518), 409413.

Lechtig, A., Habicht, J. P., Delgado, H., Klein, R. E., Yarbrough, C., \& Martorell, R. (1975). ffect of food supplementation during pregnancy on birthweight. Pediatrics, 56(4), 508-520.

Malmstrom, K., Rodriguez-Gomez, G., Guerra, J., Villaran, C., Pineiro, A., Wei, L. X., Seidenberg, B. C., \& Reiss, T. F. (1999). Oral montelukast, inhaled beclomethasone, and placebo for chronic asthma: A randomized, controlled trial. Annals of Internal Medicine, 130(6), 487-495.

Martorell, R., Habicht, J. P., Yarbrough, C., Lechtig, A., Klein, R. E., \& Western, K. A. (1975). Acute morbidity and physical growth in rural guatemalan children. American Journal of Diseases of Children, 129(11), 12961301.

Packer, M., McMurray, J. J. V., Desai, A. S., Gong, J., Lefkowitz, M. P., Rizkala, A. R., ..., \& Wong, R. C. C. (2015). Angiotensin receptor neprilysin inhibition compared with enalapril on the risk of clinical progression in surviving patients with heart failure. Circulation, 131(1), 54-61.

Pouris, A., \& Ho, Y. S. (2014). Research emphasis and collaboration in Africa. Scientometrics, 98(3), $2169-2184$.

Quan, P. L., Firth, C., Conte, J. M., Williams, S. H., Zambrana-Torrelio, C. M., Anthony, S. J., ..., \& Lipkin, W. I. (2013). Bats are a major natural reservoir for hepaciviruses and pegiviruses. Proceedings of the National Academy of Sciences of the United States of America, 110(20), 8194-8199.

Solomons, N. W. (1979). Assessment of zinc and copper nutriture in man. American Journal of Clinical Nutrition, $32(4), 856-871$.

Solomons, N. W., \& Jacob, R. A. (1981). Studies on the bioavailability of zinc in humans: Effects of heme and nonheme iron on the absorption of zinc. American Journal of Clinical Nutrition, 34(4), 475-482. 
Sosa, R., Kennell, J., Klaus, M., Robertson, S., \& Urrutia, J. (1980). The effect of a supportive companion on perinatal problems, length of labor, and mother-infant interaction. New England Journal of Medicine, 303(11), 597-600.

Soto, J., Arana, B. A., Toledo, J., Rizzo, N., Vega, J. C., Diaz, A., ..., \& Sindermann, H. (2004). Miltefosine for New World cutaneous leishmaniasis. Clinical Infectious Diseases, 38(9), 1266-1272.

Tong, S. X., Li, Y., Rivailler, P., Conrardy, C., Castillo, D. A. A., Chen, L. M., ..., \& Donis, R. O. (2012). A distinct lineage of influenza A virus from bats. Proceedings of the National Academy of Sciences of the United States of America, 109(11), 4269-4274.

Villar, J., Smeriglio, V., Martorell, R., Brown, C. H., \& Klein, R. E. (1984). Heterogeneous growth and mental development of intrauterine growth-retarded infants during the first 3 years of life. Pediatrics, 74(5), 783791.

Wang, M. H., Fu, H. Z., \& Ho, Y. S. (2011), Comparison of universities' scientific performance using bibliometric indicators. Malaysian Journal of Library \& Information Science, 16(2), 1-19. 


\section{Digital Appendix 1: Tables}

Table 1. Citations and authors according to document type.

\begin{tabular}{|c|c|c|c|c|c|c|}
\hline Document type & $T P$ & $\%$ & TC2016 & $C P P_{2016}$ & $A U$ & $A U / T P$ \\
\hline Article & 2380 & 65 & 44498 & 19 & 17696 & 7.4 \\
\hline Meeting abstract & 832 & 23 & 273 & 0.33 & 4972 & 6.0 \\
\hline Letter & 160 & 4.4 & 389 & 2.4 & 430 & 2.7 \\
\hline Review & 112 & 3.1 & 2665 & 24 & 626 & 5.6 \\
\hline Proceedings paper & 109 & 3.0 & 2251 & 21 & 523 & 4.8 \\
\hline Editorial material & 77 & 2.1 & 520 & 6.8 & 408 & 5.3 \\
\hline Note & 54 & 1.5 & 494 & 9.1 & 178 & 3.3 \\
\hline Biographical-item & 5 & 0.14 & 0 & 0 & 9 & 1.8 \\
\hline Correction & 5 & 0.14 & 1 & 0.20 & 51 & 10 \\
\hline Book review & 3 & 0.083 & 0 & 0 & 3 & 1.0 \\
\hline News item & 3 & 0.083 & 20 & 6.7 & 13 & 4.3 \\
\hline Book chapter & 1 & 0.028 & 0 & 0 & 1 & 1.0 \\
\hline Discussion & 1 & 0.028 & 0 & 0 & 1 & 1.0 \\
\hline Item about an individual & 1 & 0.028 & 0 & 0 & 3 & 3.0 \\
\hline Retraction & 1 & 0.028 & 0 & 0 & 2 & 2.0 \\
\hline
\end{tabular}

$T P:$ number of articles; $A U:$ number of authors; $T C_{2016}$ : total citations since publication to the end of 2016; $C P P_{2016}$ : citations per paper $\left(T C_{2016} / T P\right)$. 
Table 2. Citations and authors according to document language.

\begin{tabular}{lllllll}
\hline Language & $T P$ & $\%$ & $T C_{2016}$ & $C P P_{2016}$ & $A U$ & $A U / T P$ \\
\hline English & 2124 & 89 & 43765 & 21 & 16768 & 7.9 \\
Spanish & 241 & 10 & 663 & 2.8 & 866 & 3.6 \\
French & 12 & 0.50 & 55 & 4.6 & 54 & 4.5 \\
Portuguese & 2 & 0.084 & 5 & 2.5 & 5 & 2.5 \\
German & 1 & 0.042 & 10 & 10 & 3 & 3.0 \\
\hline
\end{tabular}

$T P$ : number of articles; $A U$ : number of authors; $T C_{2016}$ : total citations since publication to the end of 2016; $C P P_{2016}$ : citations per paper $\left(T C_{2016} / T P\right)$. 
Table 3. Web of Science category.

\begin{tabular}{|c|c|c|c|}
\hline Web of Science category & $T P$ & $\%$ & No. Journals \\
\hline Nutrition and Dietetics & 498 & 21 & 81 \\
\hline Public, Environmental and Occupational Health & 299 & 13 & 176 \\
\hline Tropical Medicine & 192 & 8.1 & 19 \\
\hline Pediatrics & 147 & 6.2 & 121 \\
\hline Infectious Diseases & 132 & 5.5 & 84 \\
\hline Food Science and Technology & 125 & 5.3 & 129 \\
\hline Plant Sciences & 102 & 4.3 & 211 \\
\hline Parasitology & 89 & 3.7 & 36 \\
\hline Immunology & 87 & 3.7 & 150 \\
\hline Pharmacology and Pharmacy & 84 & 3.5 & 256 \\
\hline Microbiology & 78 & 3.3 & 124 \\
\hline Entomology & 76 & 3.2 & 91 \\
\hline Agronomy & 71 & 3.0 & 83 \\
\hline Multidisciplinary Sciences & 65 & 2.7 & 64 \\
\hline Environmental Sciences & 64 & 2.7 & 229 \\
\hline Obstetrics and Gynecology & 62 & 2.6 & 80 \\
\hline Biotechnology and Applied Microbiology & 61 & 2.6 & 158 \\
\hline General and Internal Medicine & 56 & 2.4 & 154 \\
\hline Oncology & 55 & 2.3 & 217 \\
\hline Applied Chemistry & 52 & 2.2 & 72 \\
\hline Dentistry, Oral Surgery and Medicine & 52 & 2.2 & 90 \\
\hline
\end{tabular}

$T P$ : number of articles 
Table 4. Journals.

\begin{tabular}{|c|c|c|c|}
\hline Journals & $T P(\%)$ & $I F_{2016}$ & Web of Science catę \\
\hline Archivos Latinoamericanos de Nutricion & $160(6.7)$ & 0.459 & Nutrition and Dieteti \\
\hline American Journal of Clinical Nutrition & $99(4.2)$ & 6.926 & Nutrition and Dieteti \\
\hline \multirow[t]{2}{*}{ American Journal of Tropical Medicine and Hygiene } & $92(3.9)$ & 2.549 & Public, Environment: \\
\hline & & & Tropical Medicine \\
\hline Journal of Nutrition & $43(1.8)$ & 4.145 & Nutrition and Dieteti \\
\hline Plos One & $36(1.5)$ & 2.806 & Multidisciplinary Sci \\
\hline Turrialba & $26(1.1)$ & $\mathrm{N} / \mathrm{A}$ & Agronomy \\
\hline European Journal of Clinical Nutrition & $20(0.84)$ & 3.057 & Nutrition and Dieteti \\
\hline \multirow[t]{4}{*}{ Journal of Ethnopharmacology } & $20(0.84)$ & 2.981 & Plant Sciences \\
\hline & & & Chemistry, Medicina \\
\hline & & & Integrative and Com] \\
\hline & & & Pharmacology and P] \\
\hline Ecology of Food and Nutrition & $19(0.8)$ & 0.922 & Nutrition and Dieteti \\
\hline Boletin de la Oficina Sanitaria Panamericana & $18(0.76)$ & $\mathrm{N} / \mathrm{A}$ & Public, Environment: \\
\hline \multirow[t]{2}{*}{ Food and Nutrition Bulletin } & $18(0.76)$ & 1.648 & Food Science and Te \\
\hline & & & Nutrition and Dieteti \\
\hline \multirow[t]{3}{*}{ Journal of Pediatric Gastroenterology and Nutrition } & $18(0.76)$ & 2.799 & Gastroenterology anc \\
\hline & & & Nutrition and Dieteti \\
\hline & & & Pediatrics \\
\hline \multirow[t]{2}{*}{ Transactions of the Royal Society of Tropical Medicine and Hygiene } & $18(0.76)$ & 2.279 & Public, Environment \\
\hline & & & Tropical Medicine \\
\hline Reproductive Health & $17(0.71)$ & 2.209 & Public, Environment \\
\hline Florida Entomologist & $16(0.67)$ & 0.964 & Entomology \\
\hline Journal of Food Science & $16(0.67)$ & 1.815 & Food Science and Te \\
\hline Nutrition Research & $16(0.67)$ & 2.737 & Nutrition and Dieteti \\
\hline \multirow[t]{2}{*}{ American Journal of Physical Anthropology } & $15(0.63)$ & 2.552 & Anthropology \\
\hline & & & Evolutionary Biolog! \\
\hline Journal of Infectious Diseases & $15(0.63)$ & 6.273 & Immunology \\
\hline
\end{tabular}


Infectious Diseases

Microbiology

$T P$ : number of articles; $I F_{2016}$ : impact fact in 2016 ; N/A: not avalable 
Table 5. Country

\begin{tabular}{|c|c|c|c|c|}
\hline Country & $T P$ & $T P R(\%)$ & $F P R(\%)$ & $R P R(\%)$ \\
\hline USA & 1176 & $1(49)$ & $1(33)$ & $1(32)$ \\
\hline Mexico & 280 & $2(12)$ & $2(3.7)$ & $2(3.9)$ \\
\hline UK & 167 & $3(7.0)$ & $4(2.3)$ & $4(2.5)$ \\
\hline Brazil & 140 & $4(5.9)$ & $5(2.0)$ & $5(2.0)$ \\
\hline Costa Rica & 126 & $5(5.3)$ & $10(1.0)$ & $10(1.1)$ \\
\hline Spain & 125 & $6(5.3)$ & $3(3.0)$ & $3(3.3)$ \\
\hline Argentina & 119 & $7(5.0)$ & $14(0.80)$ & $14(0.82)$ \\
\hline Colombia & 104 & $8(4.4)$ & $10(1.0)$ & $10(1.1)$ \\
\hline Germany & 97 & $9(4.1)$ & $6(1.6)$ & $6(1.7)$ \\
\hline Canada & 86 & $10(3.6)$ & $7(1.4)$ & $7(1.5)$ \\
\hline France & 83 & $11(3.5)$ & $8(1.1)$ & $8(1.2)$ \\
\hline E1 Salvador & 80 & $12(3.4)$ & $37(0.042)$ & $37(0.046)$ \\
\hline Chile & 72 & $13(3.0)$ & $18(0.46)$ & $17(0.55)$ \\
\hline Honduras & 70 & $14(2.9)$ & $21(0.25)$ & $20(0.27)$ \\
\hline Peru & 68 & $15(2.9)$ & $32(0.084)$ & $30(0.092)$ \\
\hline India & 67 & $16(2.8)$ & $32(0.084)$ & $30(0.092)$ \\
\hline Italy & 64 & $17(2.7)$ & $13(0.84)$ & $13(0.87)$ \\
\hline Netherlands & 63 & $18(2.6)$ & $16(0.67)$ & $15(0.73)$ \\
\hline Switzerland & 61 & $19(2.6)$ & $12(0.92)$ & $12(0.92)$ \\
\hline Panama & 56 & $20(2.4)$ & $25(0.21)$ & $23(0.23)$ \\
\hline
\end{tabular}


$T P$ : number of articles; $F P$ : number of first author articles; $T P$ : number of corresponding author articles; $R$ : rank 
Table 6. Institutions in Guatemala.

\begin{tabular}{|c|c|c|c|c|c|c|}
\hline \multirow{2}{*}{$\begin{array}{l}\text { Institute } \\
\text { Instituto de Nutrición de Centro América y Panamá (INCAP) }\end{array}$} & \multirow[b]{2}{*}{602} & \multirow{2}{*}{$\begin{array}{l}T P T P R \\
(\%) \\
1(25)\end{array}$} & \multirow{2}{*}{$\begin{array}{l}S P R \\
(\%) \\
1(53)\end{array}$} & \multirow{2}{*}{$\begin{array}{l}C P R \\
(\%) \\
2(17)\end{array}$} & \multicolumn{2}{|c|}{$F P R(\%) R P R(\%)$} \\
\hline & & & & & $1(16)$ & $1(16)$ \\
\hline Universidad de San Carlos & 359 & $2(15)$ & $3(5.5)$ & $1(18)$ & $2(3.5)$ & $3(3.1)$ \\
\hline Universidad del Valle, Guatemala & 332 & $3(14)$ & $2(7.3)$ & $3(16)$ & $3(3.4)$ & $2(3.4)$ \\
\hline Center Studies Sensory Impairment Aging \& Metabolism & 143 & $4(6.0)$ & $5(3.2)$ & $4(6.9)$ & $4(2.7)$ & $4(2.8)$ \\
\hline Ministerio de Salud Pública y Asistencia Social & 87 & $5(3.7)$ & $\begin{array}{l}12 \\
(0.71)\end{array}$ & $5(4.6)$ & $14(0.21)$ & $15(0.18)$ \\
\hline Hospital General San Juan de Dios & 53 & $6(2.2)$ & $6(1.8)$ & $7(2.4)$ & $6(0.63)$ & $6(0.60)$ \\
\hline Universidad Francisco Marroquín & 52 & $7(2.2)$ & $\begin{array}{l}13 \\
(0.53)\end{array}$ & $6(2.7)$ & $8(0.46)$ & $7(0.50)$ \\
\hline Hospital Roosevelt & 40 & $8(1.7)$ & $7(1.4)$ & $8(1.8)$ & $7(0.5)$ & $7(0.50)$ \\
\hline Central American Research Institute for Industry & 36 & $9(1.5)$ & $4(5.3)$ & $32(0.33$ & $5(1.3)$ & $5(1.4)$ \\
\hline Centers Disease Control \& Prevention, Salvador Office & 22 & $10(0.9$ & ) $\mathrm{N} / \mathrm{A}$ & $9(1.2)$ & $19(0.13)$ & $18(0.14)$ \\
\hline Unidad Nacional de Oncología y Pediatría & 17 & $11(0.7$ & ) $\mathrm{N} / \mathrm{A}$ & $10(0.93$ & $\begin{array}{l}45 \\
(0.042)\end{array}$ & $\mathrm{N} / \mathrm{A}$ \\
\hline Hospital Herrera Llerandi & 14 & $12(0.5$ & ) $\mathrm{N} / \mathrm{A}$ & $11(0.77$ & $\mathrm{N} / \mathrm{A}$ & $\mathrm{N} / \mathrm{A}$ \\
\hline Hospital Ojos y Oídos Dr. Rodolfo Robles V. & 13 & $13(0.5$ & $8(1.2)$ & $32(0.33)$ & ) $10(0.29)$ & $10(0.32)$ \\
\hline Universidad Rafael Landívar & 13 & $13(0.5$ & ) N/A & & $\begin{array}{l}45 \\
(0.042)\end{array}$ & $\begin{array}{l}43 \\
(0.046)\end{array}$ \\
\hline Instituto de Etnobiología & 12 & $15(0.5$ & ) $\mathrm{N} / \mathrm{A}$ & $13(0.66$ & $\mathrm{N} / \mathrm{A}$ & $\mathrm{N} / \mathrm{A}$ \\
\hline $\begin{array}{l}\text { Servicio Nacional de Control de Enfermedades Transmitidas por } \\
\text { Vectores Artrópodos }\end{array}$ & 12 & $15(0.5$ & $\begin{array}{l}15 \\
(0.36)\end{array}$ & $17(0.55$ & ) $19(0.13)$ & $18(0.14)$ \\
\hline
\end{tabular}


Table 7. Authors from Guatemala.

\begin{tabular}{|c|c|c|c|c|}
\hline Author & Affiliation & $T P$ & Rank $(T P)$ & Rank $(F P)$ \\
\hline Solomons, NW & CeSSIAM & 208 & $1(208)$ & $1(65)$ \\
\hline Bressani, R & Inst Invest & 178 & $2(178)$ & $2(55)$ \\
\hline Elias, LG & Inst Nutr Cent Amer y Panamá & 63 & $3(63)$ & $26(6)$ \\
\hline Rolz, C & Univ Valle Guatemala & 52 & $4(52)$ & $3(22)$ \\
\hline Cáceres, A & Univ San Carlos USAC & 45 & $5(45)$ & $8(15)$ \\
\hline Torun, B & INCAP & 44 & $6(44)$ & $6(16)$ \\
\hline Garces, A & Francisco Marroquín Univ & 39 & $7(39)$ & $48(4)$ \\
\hline Ramírez-Zea, M & Inst Nutr Cent América y Panamá INCAP & 37 & $8(37)$ & $86(3)$ \\
\hline Habicht, JP & Inst Nutr Cent Amér y Panamá & 35 & $9(35)$ & $86(3)$ \\
\hline Lechtig, A & Inst Nutr Cent Amér y Panamá & 34 & $10(34)$ & $6(16)$ \\
\hline Yarbrough, C & Inst Nutr Cent Amér y Panamá & 34 & $10(34)$ & $86(3)$ \\
\hline Vossenaar, M & CeSSIAM & 33 & $12(33)$ & $10(13)$ \\
\hline Braham, JE & Inst Nutr Cent Amér y Panamá & 32 & $13(32)$ & $86(3)$ \\
\hline Mazariegos, M & Inst Nutr Cent Amér y Panamá & 32 & $13(32)$ & $19(7)$ \\
\hline Delgado, $\mathrm{H}$ & Inst Nutr Cent Amér y Panamá & 29 & $15(29)$ & $48(4)$ \\
\hline Cruz, JR & Inst Nutr Cent Amér y Panamá & 28 & $16(28)$ & $4(18)$ \\
\hline Barnoya, J & Cardiovasc Unit Guatemala & 26 & $17(26)$ & $38(5)$ \\
\hline Monroy, C & Univ San Carlos & 26 & $17(26)$ & $48(4)$ \\
\hline Zea-Flores, G & Ministerio de Salud de Guatemala & 25 & $19(25)$ & $354(1)$ \\
\hline Bulux, J & Hosp Ojos y Oídos Dr. Rodolfo Robles V. & 24 & $20(24)$ & $38(5)$ \\
\hline Pineda, $\mathrm{O}$ & Inst Nutr Cent Amér y Panamá & 24 & $20(24)$ & $153(2)$ \\
\hline Lindblade, KA & CDC Reg Off Cent Amer \& Panama & 23 & $22(23)$ & $38(5)$ \\
\hline Molina, MR & Inst Nutr Cent Amér y Panamá & 23 & $22(23)$ & $9(14)$ \\
\hline Belizan, JM & Inst Nutr Cent Amér y Panamá & 21 & $24(21)$ & $17(8)$ \\
\hline Dearriola, MC & Cent Amer Inst Res Ind & 20 & $25(20)$ & 354 (1) \\
\hline
\end{tabular}

$T P:$ number of articles; $F P:$ number of first author articles; $R P$ : number of corresponding author articles; $R P:$ number of single author articles; $R$ : rank. 
Table 8. Top 20 articles with over 200 total citations until the year $2016\left(T C_{2016}>200\right)$.

\begin{tabular}{|c|c|c|c|c|c|}
\hline $\begin{array}{l}\text { Rank } \\
\left(T C_{2016}\right)\end{array}$ & $\begin{array}{l}\text { Rank } \\
\left(C_{0}\right)\end{array}$ & $\begin{array}{l}\text { Rank } \\
\left(C_{2016}\right)\end{array}$ & $\begin{array}{l}\text { Rank } \\
(T C P Y)\end{array}$ & Title & Country \\
\hline $1(676)$ & $180(1)$ & $3(139)$ & $2(97)$ & $\begin{array}{l}\text { Human papillomavirus genotype attribution in } \\
\text { invasive cervical cancer: a retrospective cross- } \\
\text { sectional worldwide study }\end{array}$ & $\begin{array}{l}\text { Spain, Netherlands, Portugal, Color } \\
\text { Korea, Peru, Mexico, Brazil, Taiwa } \\
\text { Paraguay, Bosnia \& Herceg, Ugand } \\
\text { Lebanon, Croatia, Turkey, India, Gı } \\
\text { Nigeria, Philippines, Bangladesh, T } \\
\text { Australia, Japan, Honduras, Algeria } \\
\text { Republic, USA, Kuwait, Greece, Vı } \\
\text { Poland, Israel }\end{array}$ \\
\hline $2(409)$ & $13(9)$ & $72(8)$ & $16(23)$ & $\begin{array}{l}\text { Oral montelukast, inhaled beclomethasone, and } \\
\text { placebo for chronic asthma - A randomized, } \\
\text { controlled trial }\end{array}$ & USA, Costa Rica, Guatemala, Peru \\
\hline $3(402)$ & $1(60)$ & $1(200)$ & $1(134)$ & $\begin{array}{l}\text { Ramucirumab monotherapy for previously treated } \\
\text { advanced gastric or gastro-oesophageal junction } \\
\text { adenocarcinoma (REGARD): an international, } \\
\text { randomised, multicentre, placebo-controlled, phase } \\
3 \text { trial }\end{array}$ & $\begin{array}{l}\text { USA, Czech Republic, South Korea } \\
\text { India, Brazil, UK, Canada, Russia, } \\
\text { Guatemala, Poland, Spain }\end{array}$ \\
\hline $4(397)$ & $47(3)$ & $35(12)$ & $17(22)$ & $\begin{array}{l}\text { Prevention of diarrhea and pneumonia by zinc } \\
\text { supplementation in children in developing } \\
\text { countries: Pooled analysis of randomized } \\
\text { controlled trials }\end{array}$ & $\begin{array}{l}\text { USA, Pakistan, Jamaica, UK, Indon } \\
\text { Bangladesh, Vietnam, Peru, Mexicc } \\
\text { India }\end{array}$ \\
\hline $5(392)$ & $2(41)$ & $6(66)$ & $4(78)$ & A distinct lineage of influenza A virus from bats & USA, Guatemala \\
\hline $6(311)$ & $79(2)$ & $115(6)$ & $63(7.2)$ & $\begin{array}{l}\text { Height and weight standards for preschool-children } \\
\text { - how relevant are ethnic differences in growth } \\
\text { potential }\end{array}$ & Guatemala \\
\hline $7(309)$ & $180(1)$ & $1088(0)$ & $50(8.1)$ & Assessment of zinc and copper nutriture in man & Guatemala \\
\hline $8(305)$ & $475(0)$ & $41(10)$ & $21(18)$ & $\begin{array}{l}\text { Therapeutic effects of oral zinc in acute and } \\
\text { persistent diarrhea in children in developing } \\
\text { countries: pooled analysis of randomized } \\
\text { controlled trials }\end{array}$ & $\begin{array}{l}\text { USA, Pakistan, UK, Jamaica, Indon } \\
\text { Bangladesh, Vietnam, Peru, Mexicc } \\
\text { India }\end{array}$ \\
\hline $9(260)$ & $17(7)$ & $2(146)$ & $3(87)$ & $\begin{array}{l}\text { Secukinumab in Plaque Psoriasis - Results of Two } \\
\text { Phase } 3 \text { Trials }\end{array}$ & $\begin{array}{l}\text { Canada, USA, Germany, UK, Spain } \\
\text { Australia, Iceland, Guatemala, Taiu }\end{array}$ \\
\hline $10(256)$ & $475(0)$ & $648(1)$ & $65(7.1)$ & $\begin{array}{l}\text { Studies on the bioavailability of zinc in humans - } \\
\text { effects of heme and nonheme iron on the } \\
\text { absorption of zinc }\end{array}$ & USA, Guatemala \\
\hline $11(255)$ & $30(4)$ & $648(1)$ & $59(7.5)$ & $\begin{array}{l}\text { Reduction of blood-pressure with calcium } \\
\text { supplementation in young-adults }\end{array}$ & USA, Guatemala \\
\hline $12(254)$ & $475(0)$ & $150(5)$ & $69(6.9)$ & $\begin{array}{l}\text { The effect of a supportive companion on perinatal } \\
\text { problems, length of labor, and mother-infant } \\
\text { interaction }\end{array}$ & USA, Guatemala \\
\hline $13(239)$ & $475(0)$ & $5(67)$ & $6(48)$ & Averting biodiversity collapse in tropical forest & $\begin{array}{l}\text { Australia, Panama, UK, USA, Mexi } \\
\text { China, Canada, Denmark, Surinam, }\end{array}$ \\
\hline
\end{tabular}


protected areas

$\begin{array}{llll}14(235) & 475(0) & 115(6) & 82(6.2) \\ 15(227) & 10(10) & 423(2) & 35(11) \\ 16(220) & 475(0) & 423(2) & 73(6.7)\end{array}$

$17(214) \quad 475(0) \quad 648(1)$

$18(207) \quad 475(0) \quad 1088(0)$

$19(202) \quad 17(7) \quad 13(36)$

$19(202) \quad 30(4) \quad 41(10)$ on birth-weight
Analysis of two genetic models for the innate components of colony odor in social Hymenoptera

An outbreak in 1996 of cyclosporiasis associated with imported raspberries
France, Thailand, Congo, India, $\mathrm{Ne}$ Costa Rica, Uganda, Italy, Austria, Bolivia, Taiwan, Venezuela, Singap Spain, Kenya, Cote Ivoire, Japan, G Republic, Papua N Guinea, Indones Sierra Leone, Cent Afr Republ, Nep

Australia, Guatemala

USA, Canada, Guatemala Heterogeneous growth and mental-development of USA, Guatemala intrauterine growth-retarded infants during the first three years of life

121 (5.1) Effect of food supplementation during pregnancy Guatemala

132 (4.9) Acute morbidity and physical growth in rural Guatemala, USA Guatemalan children

15 (25) Ancestry Informative Marker Sets for Determining USA, Guatemala, Sweden Continental Origin and Admixture Proportions in Common Populations in America

24 (16) Miltefosine for New World cutaneous leishmaniasis

Germany, Colombia, Guatemala, U:

$T C_{2016}:$ total citations since publication to the end of $2016 ; C_{0}$ : citations in publication year; $C_{2016}:$ citations in 2016 ;

TCPY: citations per number of years. 
Table 9. Top 10 Guatemala independent articles with $T C_{2016}>100$.

\begin{tabular}{|c|c|c|c|c|c|}
\hline $\begin{array}{l}\text { Rank } \\
\left(T C_{2016}\right)\end{array}$ & $\operatorname{Rank}\left(C_{0}\right)$ & $\begin{array}{l}\text { Rank } \\
\left(C_{2016}\right)\end{array}$ & $\begin{array}{l}\text { Rank } \\
(T C P Y)\end{array}$ & Title & Institution \\
\hline $6(311)$ & $79(2)$ & $115(6)$ & $63(7.2)$ & $\begin{array}{l}\text { Height and weight standards for preschool-children - how } \\
\text { relevant are ethnic differences in growth potential }\end{array}$ & Inst Nutr Cent Amer y Pa \\
\hline $7(309)$ & $180(1)$ & $1088(0)$ & $50(8.1)$ & Assessment of zinc and copper nutriture in man & Inst Nutr Cent Amer y Pa \\
\hline $17(214)$ & $475(0)$ & $648(1)$ & $121(5.1)$ & $\begin{array}{l}\text { Effect of food supplementation during pregnancy on } \\
\text { birth-weight }\end{array}$ & Inst Nutr Cent Amer y $\mathrm{Pa}$ \\
\hline $27(166)$ & $475(0)$ & $276(3)$ & $107(5.4)$ & $\begin{array}{l}\text { Competitive interaction of iron and zinc in the diet - } \\
\text { consequences for human-nutrition }\end{array}$ & $\begin{array}{l}\text { Inst Nutr Cent Amer y Pa } \\
\text { Sensory Impair Aging \& }\end{array}$ \\
\hline $29(164)$ & $475(0)$ & $115(6)$ & $156(4.4)$ & $\begin{array}{l}\text { The relationship between calcium intake and edema- } \\
\text { gestosis, proteinuria-gestosis, and hypertension-gestosis - } \\
\text { an hypothesis }\end{array}$ & Inst Nutr Cent Amer y Pa \\
\hline $33(153)$ & $475(0)$ & $423(2)$ & $113(5.3)$ & $\begin{array}{l}\text { Hematological effect of supplementing anemic children } \\
\text { with vitamin-a alone and in combination with iron }\end{array}$ & Inst Nutr Cent Amer y Pa \\
\hline $34(148)$ & $475(0)$ & $276(3)$ & $223(3.5)$ & $\begin{array}{l}\text { Vot discrimination by } 4 \text { to } 61 / 2 \text { month-old infants from } \\
\text { spanish environments }\end{array}$ & Inst Nutr Cent Amer y $\mathrm{Pa}$ \\
\hline $57(121)$ & $475(0)$ & $648(1)$ & $267(3.2)$ & $\begin{array}{l}\text { Possible effects of seed coat polyphenolics on the } \\
\text { nutritional quality of bean protein }\end{array}$ & Inst Nutr Cent Amer y $\mathrm{Pa}$ \\
\hline $58(118)$ & $475(0)$ & $648(1)$ & $209(3.7)$ & $\begin{array}{l}\text { Open, prospective-study of the clinical efficacy of } \\
\text { ciprofloxacin }\end{array}$ & Roosevelt Hosp; San Juar \\
\hline $68(102)$ & $475(0)$ & $115(6)$ & $144(4.6)$ & $\begin{array}{l}\text { Antigonorrhoeal activity of plants used in Guatemala for } \\
\text { the treatment of sexually-transmitted diseases }\end{array}$ & Univ San Carlos; Farmay: \\
\hline
\end{tabular}

$T C_{2016}$ : total citations since publication to the end of 2016; $C_{0}$ : citations in publication year; $C_{2016}$ : citations in 2016;

$T C P Y$ : citations per number of years. 


\section{Digital Appendix 2. Additional Figures}

Figure 5. Percentage of publications and number of journals in each Web of Science category.

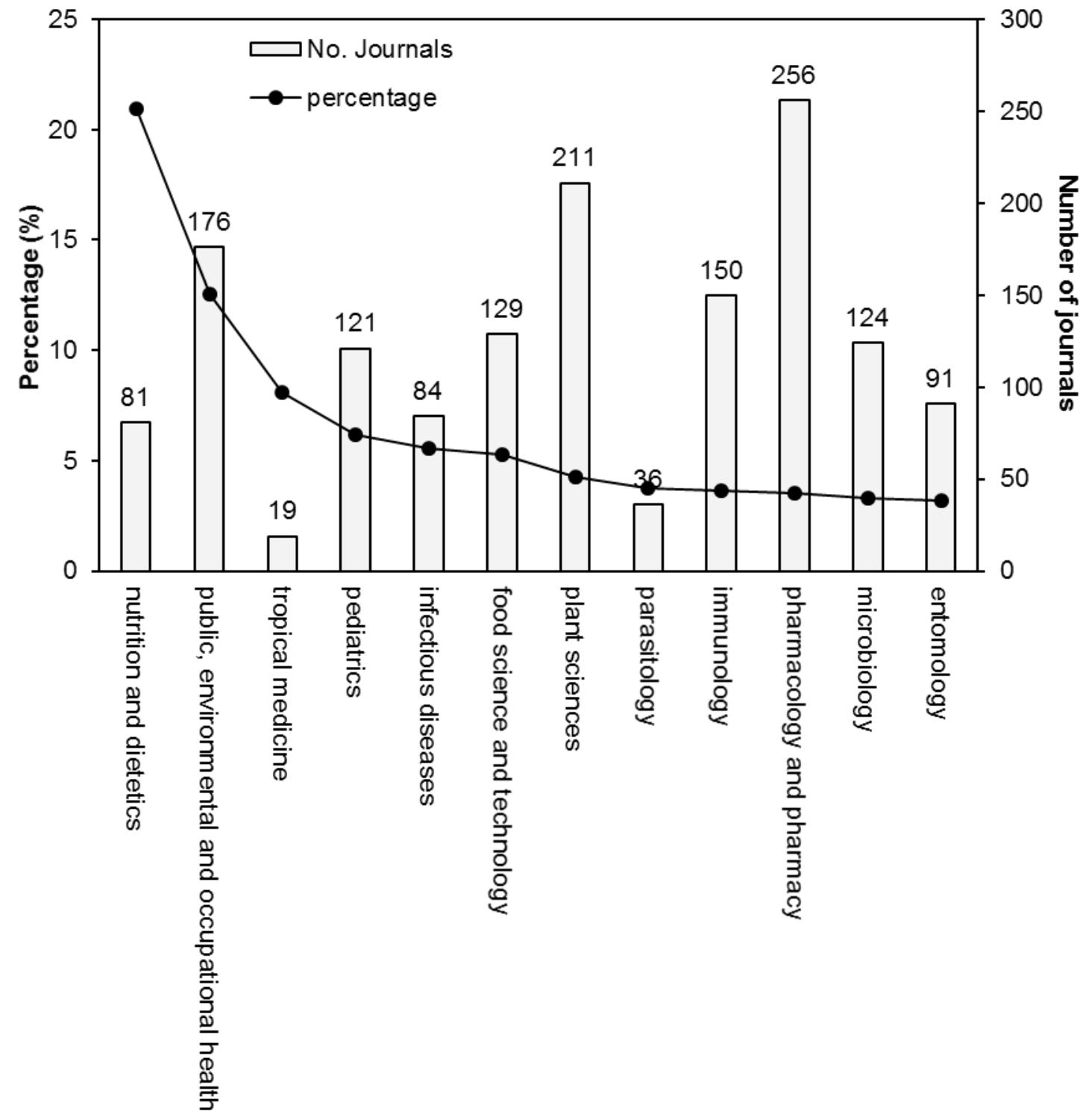


Figure 6. Historical collaboration pattern for the top six collaborative countries with Guatemala $(T P>120)$.

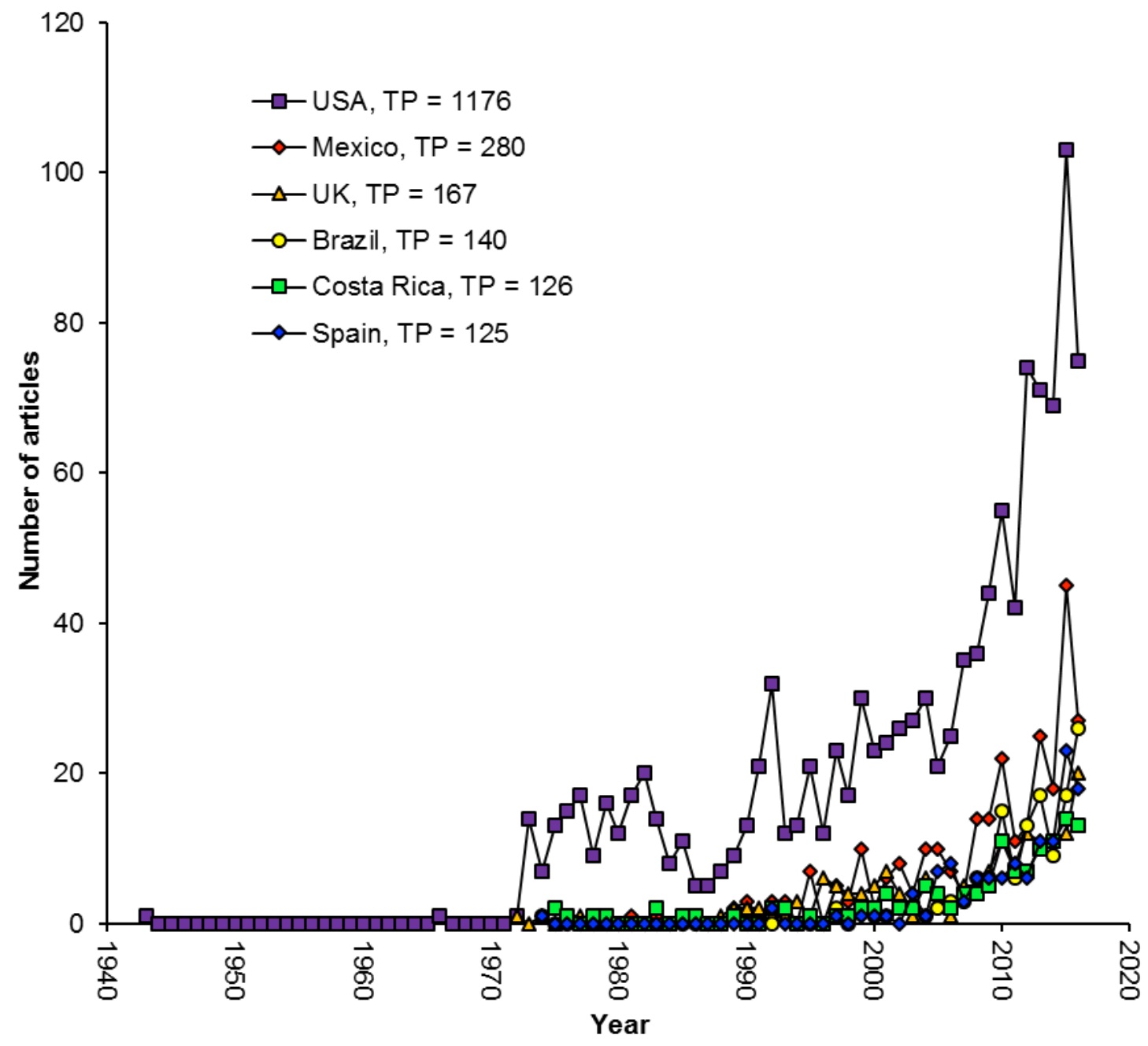


Figure 7. Historical collaboration pattern for Guatemala, by geographically closest countries.

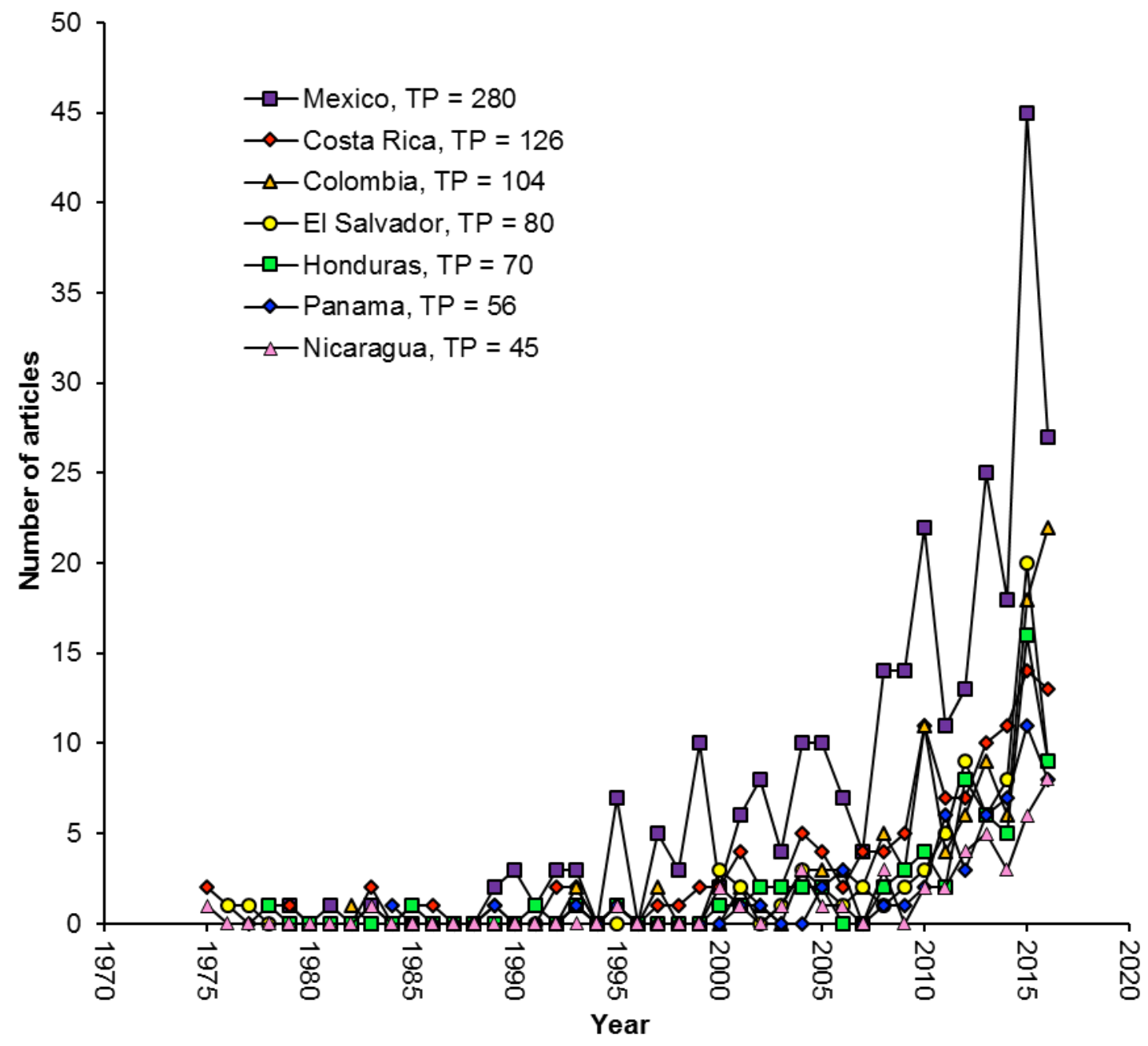


Figure 8. Historical citation patterns for top cited articles, by publication year $\left(C_{0}>10\right)$.

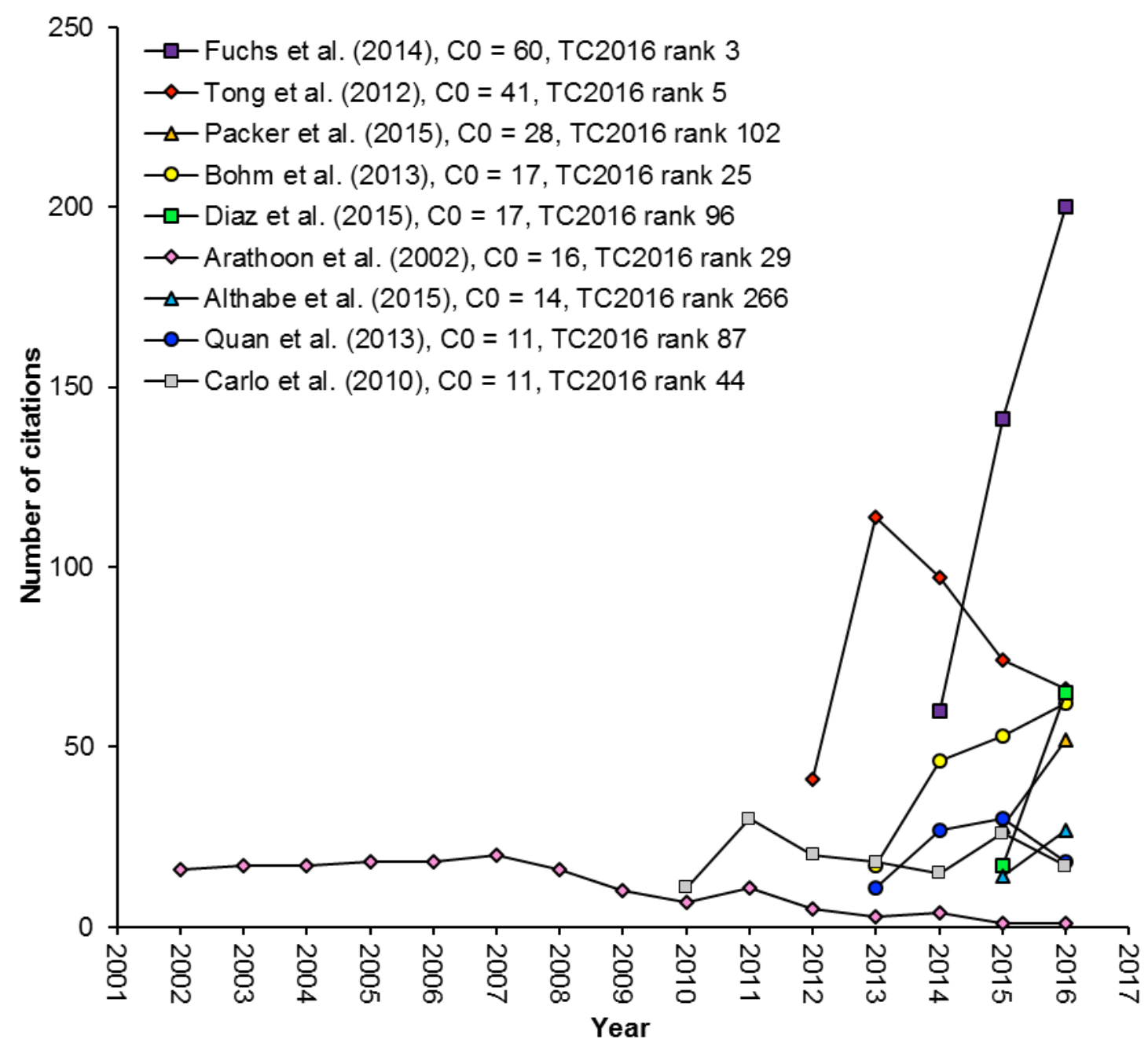


Figure 9. Article lifespan for top cited articles, by publication year $\left(C_{0}>10\right)$.

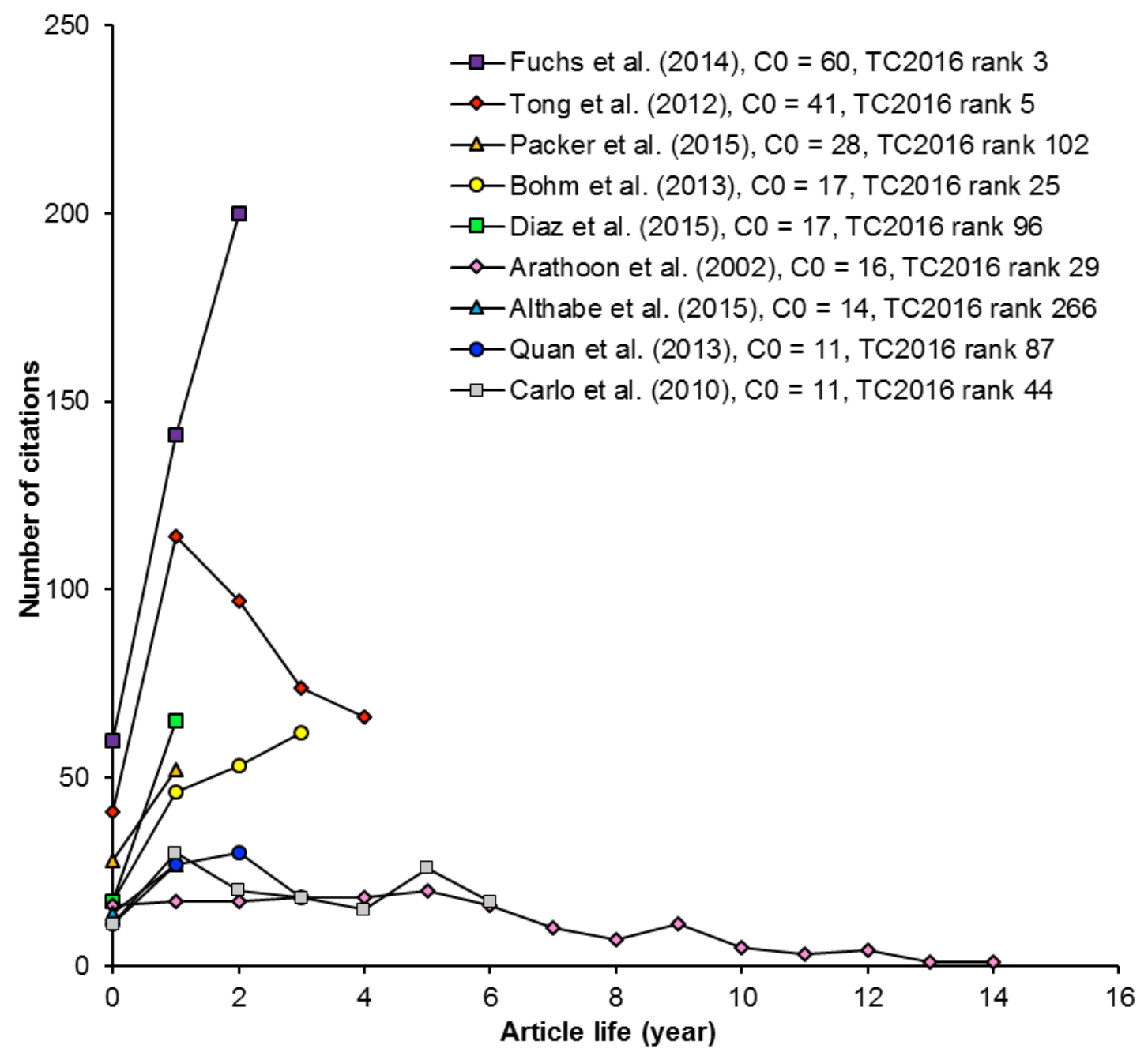


Figure 10. Historical citation patterns for top cited articles in 2016 (recent year) only $\left(\mathrm{C}_{2016}>50\right)$.

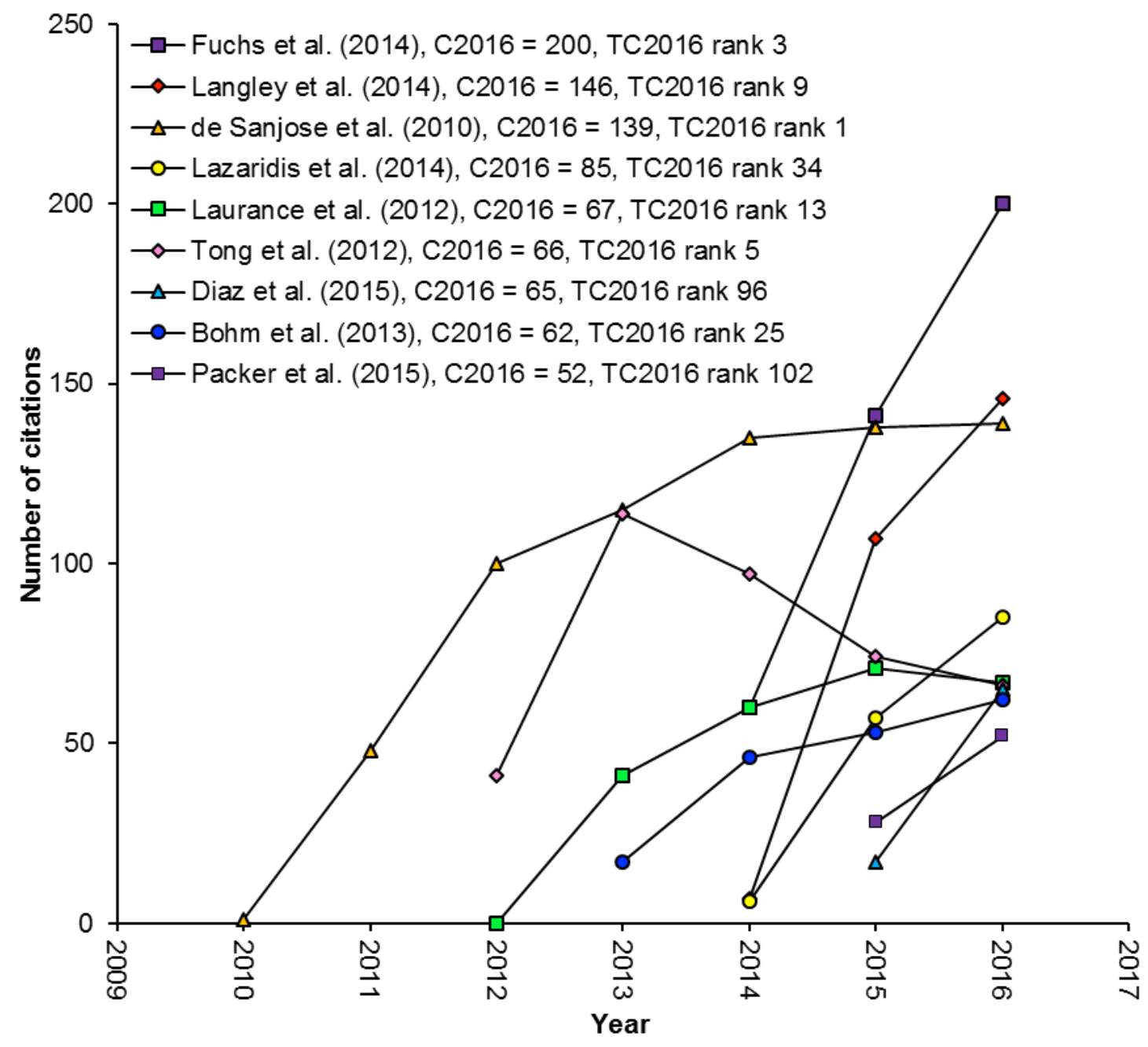


Figure 11. Historical citation patterns for top cited articles by total citations per year $(T C P Y \geq 40)$.

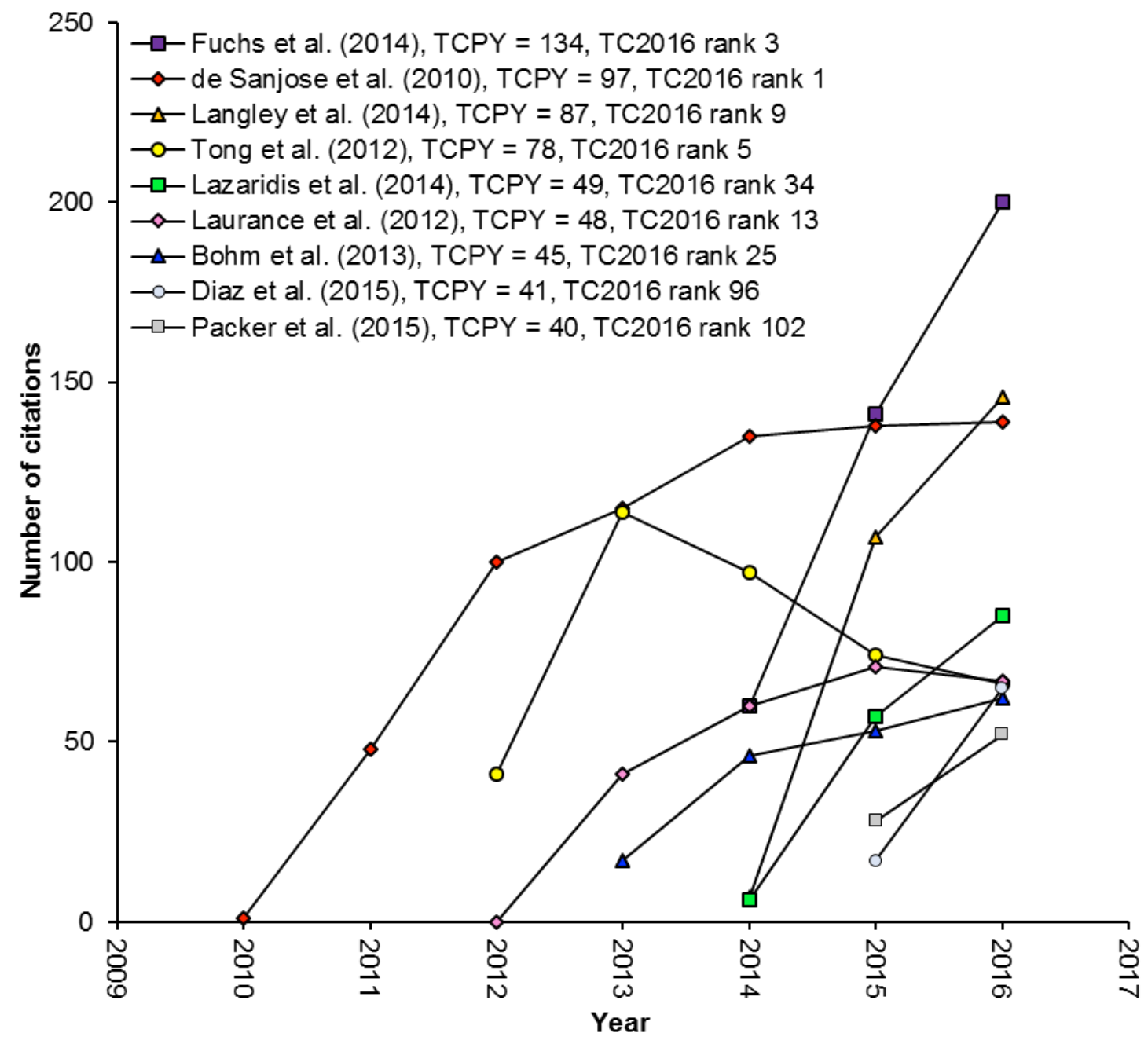


Figure 12. Historical citation patterns for four articles ranked on both the top ten $T C_{2016}$ and $C_{2016}$.

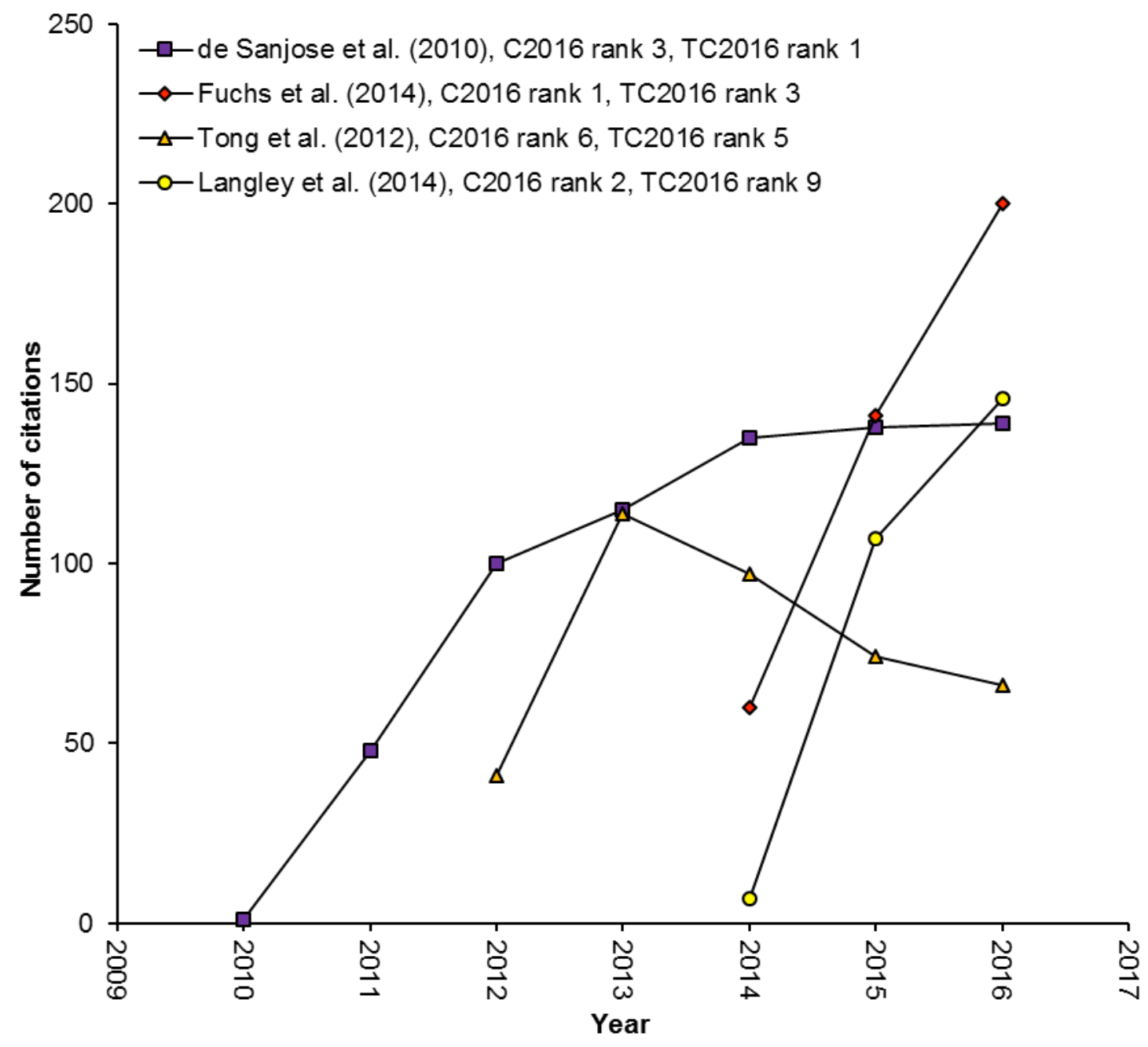


Figure 13. Publication trends for the top six institutions $(T P>50)$.

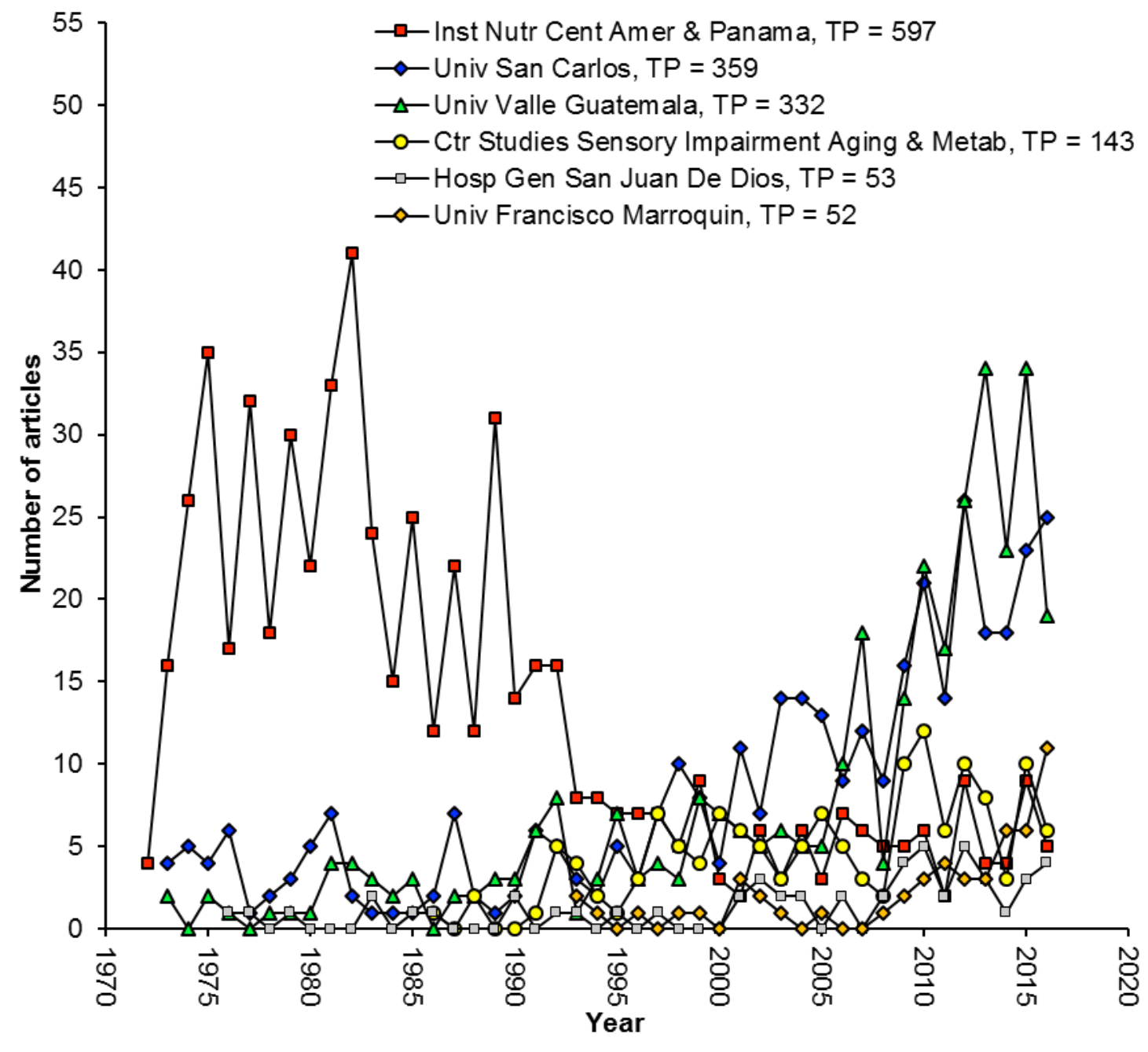


Figure 14. Historical number of article patterns for Guatemala, by the top five Web of Science category.

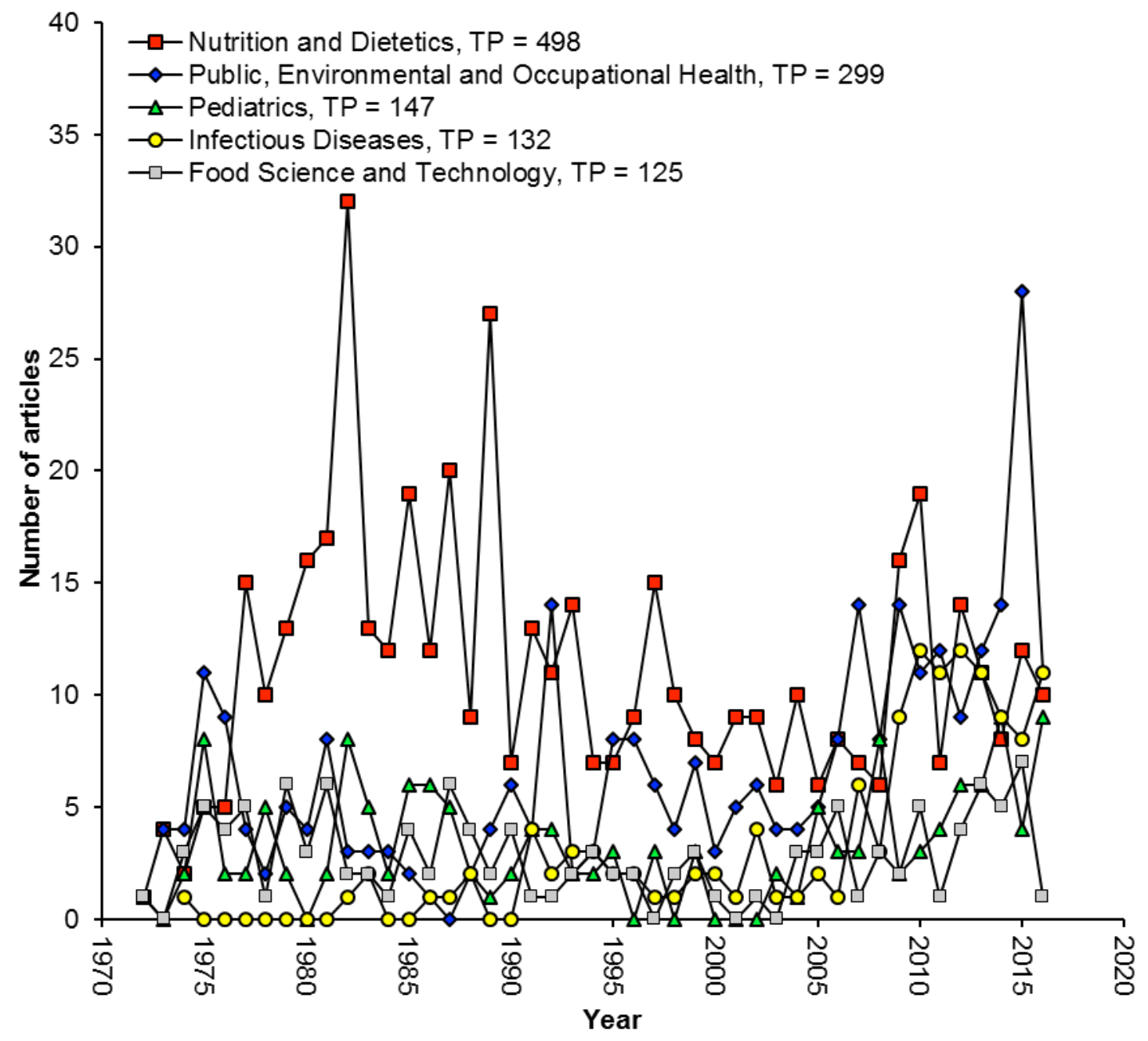

